\title{
Review \\ Gastrointestinal Tumors: Phytochemical and Drug Combinations Targeting the Hallmarks of Cancer
}

\author{
Emanuele Salvatore Scarpa ${ }^{1, *}$, Marco Giammanco ${ }^{2}$ and Mauro Magnani $^{1}{ }^{1}$ \\ 1 Department of Biomolecular Sciences, University of Urbino Carlo Bo, 61029 Urbino, Italy; \\ mauro.magnani@uniurb.it \\ 2 Department of Surgical, Oncological and Oral Sciences (DICHIRONS), University of Palermo, \\ 90127 Palermo, Italy; marco.giammanco@unipa.it \\ * Correspondence: emanuele.scarpa@uniurb.it
}

Citation: Scarpa, E.S.; Giammanco, M.; Magnani, M. Gastrointestinal Tumors: Phytochemical and Drug Combinations Targeting the Hallmarks of Cancer. Appl. Sci. 2021, 11, 10077. https://doi.org/ 10.3390/app112110077

Academic Editor: Maria Stefania Sinicropi

Received: 1 September 2021

Accepted: 23 October 2021

Published: 27 October 2021

Publisher's Note: MDPI stays neutral with regard to jurisdictional claims in published maps and institutional affiliations.

Copyright: (c) 2021 by the authors. Licensee MDPI, Basel, Switzerland. This article is an open access article distributed under the terms and conditions of the Creative Commons Attribution (CC BY) license (https:// creativecommons.org/licenses/by/ $4.0 /)$.

\begin{abstract}
Cancer is a worldwide burden resulting in millions of deaths each year. In particular, gastrointestinal tumors are life-threatening malignancies and one of the leading reasons for death in developed countries. Phytochemicals can be found in grains, vegetables, fruits and several foods. Many phytochemicals, such as curcumin, genistein, luteolin, vitexin-2-O-xyloside, avenanthramides, quercetin, epigallocatechin-3-gallate (EGCG), resveratrol, sulforaphane, piperine and thymoquinone have been used in combination with different chemotherapeutic agents for their synergistic anticancer effects against various forms of cancer. In this review, we describe the antitumor properties and biological effects of combinations of phytochemicals and anticancer drugs against gastrointestinal tumors: colon cancer, gastric cancer, liver cancer, pancreatic cancer. We focus on the molecular pathways, oncoproteins and tumor suppressors modulated by the combination of phytochemicals with antitumor drugs and on the biomarkers of the hallmarks of cancer influenced by these therapeutic strategies in cancer cell lines, xenograft models and clinical trials. The increased knowledge of biomarkers and molecular pathways regulated by the combination of phytochemicals and conventional anticancer drugs in both in vitro and in vivo models will remarkably improve the efficacy of these therapeutic strategies against gastrointestinal tumors in future innovative clinical applications.
\end{abstract}

Keywords: hallmarks of cancer; oncogenes; phytochemicals; anticancer drugs; gastrointestinal tumors

\section{Introduction}

Carcinogenesis is the process that characterizes the transformation of normal cells into tumor cells [1]. This process is driven by the accumulation of genetic mutations and the alteration of epigenetic regulatory mechanisms [1]. During metastasis development, the spreading of primary tumor cells to distant tissues and organs takes place [2]; the metastasis cascade consists of five steps: invasion; intravasation; systemic transportation; extravasation and colonization of the new site [3]. Metastasis formation is linked to the Epithelial to Mesenchymal Transition (EMT) process [4]. In the EMT multiple, distinct cellular subpopulations are involved, including the cancer stem cells (CSCs), that can regenerate the cells of the tumor core [5]. It has been demonstrated that the cells of the core of tumor mass live in hypoxic conditions, resulting in activation of hypoxia inducible factors (HIF-1 $\alpha$ and HIF-2 $\alpha$ ), that are able to increase the expression of several genes, such as vascular endothelial growth factor $\mathrm{A}$ (VEGFA), leading to events of neo-angiogenesis and enhancement of vessel permeability [6]. In particular, HIF-1 $\alpha$ is an essential protein for EMT activation and metastasis development [7]. Importantly, there are two kinds of antitumor drugs used against tumors characterized by metastasis development: anti-angiogenic and anti-metastatic synthetic molecules; these drugs target specific characteristics of tumor cells, called hallmarks of cancer [8]. The hallmarks of cancer include: increased signaling for proliferation, evading growth inhibitors, evading apoptosis, replicative immortality, increased angiogenesis, activated invasion and metastasis development, genome mutations, 
pro-inflammatory conditions, altered energy metabolism and evading immune destruction, to which the tumor micro-environment contributes [1]. Furthermore, another hallmark plays a pivotal role in cancer development: the multidrug resistance (MDR) of cancer cells, acquired through overexpression of MDR genes and increased levels of P-glycoprotein (P-gp), which is involved in the efflux of chemotherapeutic drugs from tumor cells [9].

Conventional anticancer drugs specifically target over-proliferating tumor cells; importantly, new therapeutic strategies have been developed, focused on a combination of chemotherapeutic agents and chemoprevention [10]. The role of diet in tumor chemoprevention has been indicated by many authors, who described the relationship between phytochemicals present in food and their antitumor properties [11-13]. Apoptosis is the main mechanism through which phytochemicals induce the death of tumor cells, after the activation of specific enzymes called caspases [14]. Three apoptotic pathways have been described: the extrinsic pathway, where caspase 8, caspase 3 and the multi-protein complex Fas-associated protein with death domain (FADD)osome (Figure 1) play a pivotal role [1], endoplasmic reticulum pathway [15] and the intrinsic pathway [1], where caspases 2, 9 and 3 are involved $[16,17]$. As regards caspase 2, this enzyme is activated by reactive oxygen species (ROS). The role of ROS, increased DNA damage and multi-protein complex p53-induced death domain containing protein (PIDD)osome (Figure 1) in the maturation and activation of caspase 2 has been described [16]. Noteworthy, inhibitor of apoptosis proteins (IAPs) are able to suppress the intrinsic pathway of apoptosis, in particular through an increase of Baculoviral inhibitor of apoptosis repeat-containing 5 (BIRC5) expression levels and survivin protein levels [18]. This IAP can inhibit the caspase 9 activity, blocking the formation of the apoptosome (Figure 1) [18].
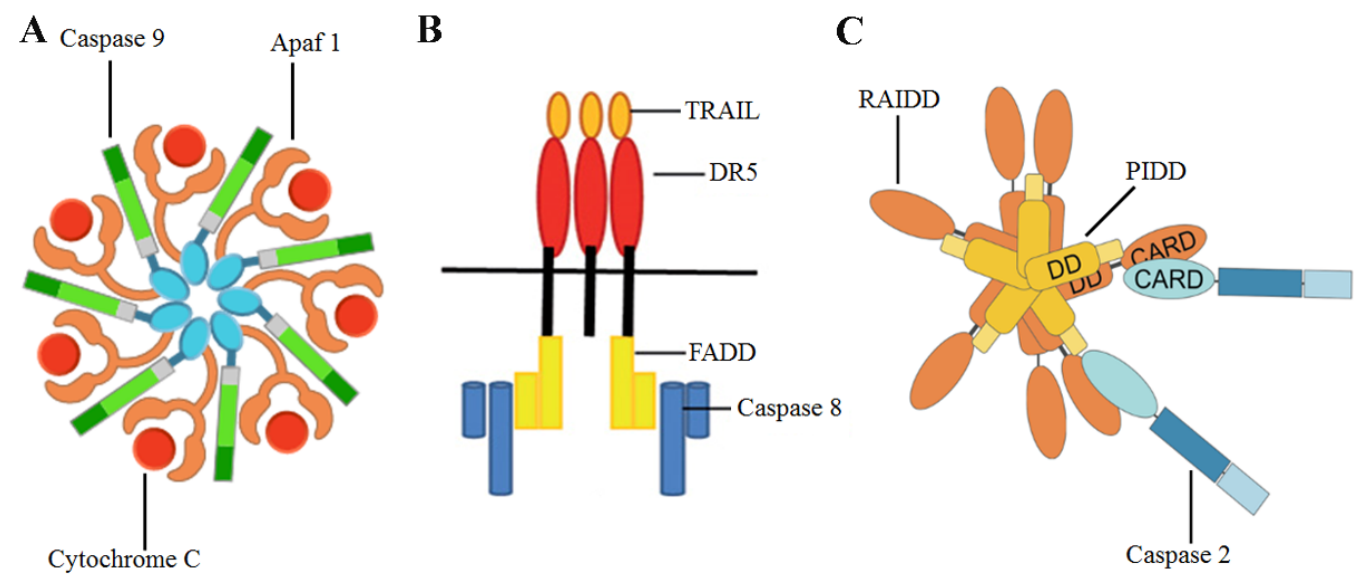

Figure 1. Graphical representations of (A) apoptosome, (B) FADDosome, (C) PIDDosome. TRAIL: TNF-related apoptosis inducing ligand, DR5: Death Receptor 5, RAIDD: RIP-associated ICH1/CED3homologous protein with a death domain.

Several phytochemicals and synthetic molecules derived from natural compounds can activate the intrinsic or the extrinsic apoptotic pathways [19-22]. Interestingly, it has been shown that a phytochemical combination of moringin (MOR) and avenanthramide $2 \mathrm{f}$ was able to induce the activation of caspases $8,9,2$ and 3 in the hepatocarcinoma Hep3B cells, leading to a significant decrease of their proliferation rate [23]. Importantly, several plant phytochemicals possess both antiproliferative and proteasome-inhibitory activity, including epigallocatechin-3-gallate (EGCG), genistein, luteolin, apigenin, chrysin, quercetin, curcumin and tannic acid. These polyphenols have exhibited an appreciable effect on overcoming resistance to various chemotherapeutic drugs as well as multidrug resistance in a broad spectrum of tumors ranging from carcinomas and sarcomas to hematological malignancies [24].

Eukaryotic proteasome 26S consists of the 20S core and two 19S caps [25]. Interestingly, proteasome activity can modulate the levels of B-cell leukemia/lymphoma 2 (Bcl-2) family proteins, Nuclear factor-kappa B (NF-kB), p53-Mouse double minute 2 homolog (MDM2) 
complex and other oncoproteins and tumor suppressors [26]. It was shown that enhanced proteasome activity, in turn, promotes the degradation of tumor suppressor proteins, resulting in cancer cell survival and proliferation as well as the development of drug resistance [27]. Noteworthy, when cancer cells acquire resistance to a specific anticancer drug, they can become cross-resistant also to chemotherapeutics which affect different molecular pathways [28]. It was shown that resistance to apoptosis induction, enhancement of drug efflux, improvement of drug detoxification and modification of drug targets are the mechanisms with a pivotal role in the acquisition of drug resistance capabilities [28]. Importantly, it was demonstrated that the increased proteasome activity detected in cancer cells accelerates the turnover of $\mathrm{IkB} \alpha$ (the NF-kB inhibitor), leading to an accumulation of the pro-survival transcription factor NF-kB [29]. In addition, increased proteasome activity in tumor cells can accelerate the degradation of the tumor suppressor Bcl-2-like protein 4 (Bax), reducing the Bax/Bcl-2 ratio [30]. Another mechanism that leads to the MDR phenotype is represented by an increase of the drug efflux, which is mediated by ATP-binding cassette $(A B C)$ transporters, including P-gp [31]. Interestingly, it was shown that proteasome inhibitors successfully reversed the resistance to anticancer drugs in tumor cells by decreasing P-gp levels [32].

\section{Anticancer Effects of Phytochemicals Used Alone and in Combination with Anticancer Drugs}

Phytochemicals can be found in grains, vegetables, fruits and several foods [33]. Many phytochemicals, like genistein and resveratrol, were combined with different antitumor drugs for their synergistic anticancer effects against various forms of cancer [33]. Synergy effect is broadly defined as the interaction or cooperation of two or more substances to produce a combined effect greater than the sum of their individual effects [34]. Combinational treatment with phytochemicals and anticancer drugs can suppress cancer recurrence and reduce the resistance of tumor cells to chemotherapeutic agents [35]. Interestingly, green beet and red beetroot have been described as vegetables rich in phytochemicals with anticancer effects, like vitexin-2-O-xyloside, apigenin, betacyanins, betaxanthins, which possess antitumor properties against colon, liver and bladder cancers [36]. These phytochemicals are able to downregulate pro-survival genes BIRC5, catenin beta-1 (CTNNB1), HIF1A, VEGFA and to inhibit the multidrug resistance mechanisms of tumor cells [36]. Phytochemicals extracted from green beet and red beet target several proteins, which have been identified either as tumor suppressors, like Bax, FS-7-associated surface antigen (Fas), p53, Bcl-2-associated agonist of cell death (Bad), TRAIL, or as oncoproteins, like Bcl-2, Cyclooxygenase-2 (COX-2), Survivin, $\beta$-catenin, HIF1 $\alpha$, VEGF [36]. Importantly, the chemopreventive and antitumor properties of several other phytochemicals, like curcumin, resveratrol, sulforaphane and piperine have been demonstrated. The chemopreventive action of curcumin and its synergistic effects, when combined with other phytochemicals (like quercetin) and antitumor drugs (like tamoxifen and 5-fluorouracil (5-FU)) against several cancers, have already been described [37]. Curcumin can reverse the drug resistance to doxorubicin (DOX) or paclitaxel by directly inhibiting the expression of P-gp in cancer cells $[38,39]$. Resveratrol is also able to reverse drug resistance in cancer cells by directly affecting the efflux pumps. Importantly, co-administration of DOX with resveratrol led to the reversal of drug resistance in various cancer cell lines, as a result of the downregulation of Multidrug resistance-associated protein 1 (MRP1) and the reduced expression of P-gp [40]. Interestingly, it was shown that sulforaphane re-sensitized Barrett esophageal adenocarcinoma cells to the effects of the drug paclitaxel [41]. Importantly, piperine has been extensively used to enhance the oral bioavailability of various drugs as it significantly inhibits the expression of Cytochrome P450 (CYP3A4) and P-gp [42]. Bioavailability of anticancer drugs enhanced by piperine includes docetaxel, etoposide and 5-FU [43-45]. In the following sections, we describe the antitumor properties and biological effects of several combinations of phytochemicals and anticancer drugs against gastrointestinal tumors: colon cancer, gastric cancer, liver cancer, pancreatic cancer. 


\subsection{Colon Cancer}

\subsubsection{Antitumor Effects of Combinations of Curcumin with Anticancer Drugs in Colon Cancer}

Extensive research has evidenced that curcumin, the main curcuminoid of turmeric (C. longa), is able to decrease the resistance of cancer cells to several chemotherapeutic agents, like gemcitabine, 5-FU, cisplatin and DOX in pancreas, colon, liver and gastric tumors [46]. It has been shown that curcumin can sensitize colorectal cancer cells to 5-FU [47]. Interestingly, the effects of a combination of curcumin and bevacizumab were studied in a xenograft model derived from the HT29 colorectal cancer cells [48]. Mice fed with curcumin showed high bioavailability of the phytochemical and the combination therapy induced remarkable anticancer effects [48]. In addition, curcumin effects were assayed in two different human colon adenocarcinoma cell lines (HCT-116 and HT-29) and the pancreatic cancer cell line Panc-28. Curcumin reduced the proliferation rate of tumor cells, regulating NF-kB and Signal transducer and activator of transcription 3 (STAT3) activity [49]. In addition, the combination of capecitabine and curcumin increased the apoptotic rate of HCT-116 cells from $5 \%$ of cells to about $50 \%$ of cells [49]. Interestingly, the combination of curcumin and irinotecan in LoVo cancer cells modulated the levels of several therapy biomarkers: Glutathione S-transferase Mu 5 (GSTM5), Protein disulfide isomerase (PDI), Peroxiredoxin 4 (PRDX4) [50]. Importantly, the combined use of irinotecan and curcumin in an in vivo model of rat colorectal carcinogenesis remarkably reduced the activity of P-gp (7-fold), inhibiting MDR mechanisms [51]. Furthermore, it was shown that the combined therapy with curcumin and irinotecan reduced cancer growth and activated the apoptotic process in HT-29 and LoVo colon cancer cells, through the modulation of Binding Immunoglobulin Protein (BIP) and C/EBP Homologous Protein (CHOP) levels [52]. In addition, the authors demonstrated that the anticancer effects of this phytochemical and drug combination were exerted through the modulation of ROS and the induction of endoplasmic reticulum (ER) stress pathway [52]. Interestingly, a preclinical investigation revealed that combination therapy with curcumin and dasatinib was highly effective in a colon cancer model. The combination caused over $95 \%$ regression of intestinal adenomas in Apc min/+ mice, which is linked to the reduced proliferation rate and increased apoptosis induction [53]. Importantly, it was shown that curcumin is able to resensitize colon cancer cells to the drug 5-FU in a 3D alginate tumor micro-environment, through the modulation of the levels of MMP9, NF-kB and C-X-C Motif Chemokine Receptor 4 (CXCR4) [54]. Interestingly, the addition of $25 \mu \mathrm{M}$ hexahydrocurcumin to a dose of $5 \mu \mathrm{M} 5$-FU exerts a synergistic effect against the growth of HT-29 cells by significantly reducing cell viability to a greater degree than monotherapy; the combination enhanced the growth inhibition of cancer cells through the downregulation of COX-2 expression [55].

\subsubsection{Antitumor Properties of Anticancer Drug and Phytochemical Combinations in Colon Cancer}

Importantly, it was demonstrated that resveratrol can reduce the resistance to 5-FU of colon cancer cells through the reduction of slug and vimentin protein levels [56]. Interestingly, in a rat model, the combination of $10 \mathrm{mg} / \mathrm{kg}$ resveratrol and $12 \mathrm{mg} / \mathrm{kg}$ cisplatin treatments reduced the side effects of the drug [57]. In order to increase the anticancer effects of resveratrol, Mohapatra et al. [58] studied the effects of the combined use of $15 \mu \mathrm{M}$ resveratrol and $0.5 \mu \mathrm{M}$ 5-FU in colon cancer HCT-116 cells. This combination led to a synergistic anticancer effect, exerted through the reduction of tumor cells proliferation rate and migration capabilities, enhancement of DNA damages, induction of the apoptotic process and block of the cell cycle in the S phase. Phosphorylation of both c-Jun N-terminal kinase (JNK) and p38 mitogen-activated protein kinases (p38 MAPK) was increased by this combination of resveratrol and 5-FU [58]. Interestingly, it was shown that a combination of 5-FU and EGCG reduced the growth of HCT116 and DLD1 colon cancer cells, through the glucose-regulated protein 78 (GRP78)/NF-kB/miR-155-5p/MDR1 pathway inhibition [59]. Importantly, it was shown that 5-FU and EGCG co-loaded nanoparticles exhibited remarkable anti-tumor activity and pro-apoptotic efficacy in both in vitro and 
in vivo colon cancer models [60]. Interestingly, the combination of EGCG and sodium butyrate induced G2/M arrest in RKO and HCT-116 colon cancer cells, and G1 arrest in HT-2 cancer cell line, through the modulation of the levels of Histone deacetylase 1 (HDAC1) and DNA (cytosine-5)-methyltransferase 1 (DNMT1) [61].

Interestingly, the combination of thymoquinone and topotecan inhibited the proliferation of colon cancer cells through caspases activation and induction of cell cycle arrest during the $S$ phase [62]. Furthermore, the authors indicated that the combination of this phytochemical with the anticancer drug remarkably reduced the growth of tumor cells without involving Bax, Bcl-2 and p53 [62]. In addition, the combination of DOX and thymoquinone reduced the proliferation rate of HT-29 colon cancer cells [63]. Interestingly, several authors studied the antiproliferative effects of thymoquinone in LoVo cancer cells resistant to the chemotherapeutic agent irinotecan, showing that this natural molecule can regulate JNK and p38 pathways affecting Extracellular signal-regulated kinases 1/2 (ERK1/2), Phosphoinositide 3-kinase (PI3K) and is also able to induce the autophagic process $[64,65]$.

Interestingly, Palko-Labuz A. et al. [66] demonstrated that the combination of baicalein and DOX in colorectal cancer cells induced the activation of caspase 3 along with DNA fragmentation, the downregulation of proliferating cell nuclear antigen (PCNA) and growth inhibition. Importantly, 5-FU and ellagic acid remarkably inhibited the growth of colon cancer cells SW480, HT-29 and Colo320DM. The synergism between these two molecules was exerted through the activation of the apoptotic process in HT-29 cells, where the authors described an increase of the Bax/Bcl-2 ratio, cleaved caspase 3 and cleaved Poly ADP-ribosyl polymerase 1 (PARP1), and also loss of mitochondrial membrane potential [67]. Interestingly, the effects of the combination of ursolic acid and capecitabine were studied in in vitro and in vivo models of colon cancer [68]. The combined treatment reduced tumor volume and distant metastases in vivo. In addition, this combination of phytochemical and anticancer drugs regulated several signaling pathways, modulating the levels of key factors such as NF-kB, STAT3, $\beta$-catenin, Epidermal growth factor receptor (EGFR), p53, p21, matrix metallopeptidase 9 (MMP-9), VEGF and intercellular adhesion molecule 1 (ICAM 1) [68]. Importantly, it was demonstrated that berberine, in combination with DOX, 5-FU, CPT or taxol, in in vitro models of colon, gastric and pancreatic cancer, induced the intrinsic apoptosis, increased apoptosis inducing factor (AIF) levels, decreased Interleukin 6 (IL6) and STAT3 levels and inhibited Janus kinase (JAK)/STAT and MAPK/ERK prosurvival pathways [69-73]. Importantly, it was shown that the combination of cetuximab and tectochrysin in HCT116 and SW480 tumor cells decreased the expression of p-EGFR and COX-2 and, in addition, inhibited NF-kB and Activator protein-1 (AP-1), inducing the death of tumor cells [74]. Interestingly, the effect of a combination of terpinen-4-ol and cetuximab was analyzed in Kirsten rat sarcoma virus (KRAS) mutated HCT116 cells and also in an in vivo mouse model, showing that this combined treatment remarkably reduced tumor growth (80-90\%) and also tumor volume (62\%) [75]. Importantly, casticin has been demonstrated to potentiate Tumor necrosis factor (TNF)-related apoptosis in colon cancer cells through downregulation of survival proteins such as Bcl-2, B-cell lymphoma extra large (Bcl-xL), survivin, X-linked inhibitor of apoptosis protein (XIAP) and cellular FLICE-like inhibitory protein (cFLIP) and upregulation of DR5 [76]. Interestingly, it was shown that the use of a combination of $\beta$-Sesquiphellandrene and thalidomide in HCT116 cells decreased the levels of anti-apoptotic proteins cFLIP, Bcl-xL, Bcl-2, cellular inhibitor of apoptosis protein 1 (c-IAP1) and survivin [77]. Furthermore, the antitumor effects of the phytochemical $\beta$-caryophyllene and the anticancer drug paclitaxel were studied in DLD-1 colorectal cancer cells, showing a synergistic inhibition of proliferation rate of tumor cells and an accumulation of the chemotherapeutic agent inside the cancer cells [78]. In addition, $\beta$-caryophyllene and $\beta$-caryophyllene oxide chemosensitized Caco- 2 tumor cells to the effects of DOX [79]. The authors indicated that these phytochemicals inhibited the MDR mechanisms of the tumor cells, enhancing DOX antiproliferative effects [79]. Interestingly, it was shown that Mistletoe extract, in combination with DOX, paclitaxel, cisplatin, doxifluridine or cyclohexamide, in experimental models of colon, liver, pancreatic 
and gastric cancer induced the apoptotic process and an increase of ROS levels [80-82]. Importantly, it was shown that a combination of irinotecan and panaxadiol decreased HCT116 proliferation rate through the activation of apoptosis and an increase of cleaved caspase 9 and caspase 3 levels [83].

Interestingly, it was shown that Vitamin D (which can be found in several foods, like cheese, meat, eggs and fish) exerts chemopreventive effects in several solid tumors, in particular in colorectal cancer [84]. In vitro studies indicated that vitamin D is able to reduce the proliferation of colorectal cancer cells through the induction of the apoptotic process, the block of the cell cycle in G1 phase and the angiogenesis inhibition [85-88]. Noteworthy, the inhibitory effects of 25-hydroxy vitamin D3 $\left(1,25(\mathrm{OH})_{2} \mathrm{D} 3\right)$ on cell proliferation and apoptosis are underlined by the findings that this molecule promotes sensitivity to the chemotherapeutic agent 5-FU by down-regulating the expression of the anti-apoptotic protein survivin and of thymidylate synthase, a key enzyme in the biosynthethic pathway of DNA [84]. Furthermore, studies on different colon carcinoma cell lines showed that $1,25(\mathrm{OH})_{2} \mathrm{D} 3$ may promote apoptosis by the up-regulation of the pro-apoptotic protein Bcl-2 homologous antagonist/killer 1 (BAK1) and the down-regulation of the nuclear anti-apoptotic protein Bcl-2-associated athanogene 1 (BAG1) [88]. Interestingly, it was demonstrated that treatment of Caco-2 colon cancer cells with $1,25(\mathrm{OH})_{2} \mathrm{D} 3$ induced an increase in the expression of p21, p27, E-cadherin, and other adhesion proteins ((Zonula occludens-1 (ZO-1), Zonula occludens-2 (ZO-2), and vinculin)) and promoted the translocation of $\beta$-catenin and ZO- 1 from the nucleus to the plasma membrane [89]. Regarding in vivo experiments, Meeker et al. [90], by using a mouse model of bacteria-driven colitis and colon cancer, when infected with Helicobacter bilis (H. bilis), showed that mice fed high vitamin $\mathrm{D}$ diet had a significantly lower incidence of cancer compared with mice fed maintenance diet. These findings further suggest that increased dietary vitamin D is beneficial in preventing inflammation-associated colon cancer through the suppression of inflammatory responses during the initiation of neoplasia or early-stage carcinogenesis [84]. The molecular pathways and molecular targets modulated by the combinations of phytochemicals and anticancer drugs in colon cancer models are reported in Table 1.

Table 1. Colon cancer targets.

\begin{tabular}{|c|c|c|c|}
\hline $\begin{array}{l}\text { Phytochemical-Drug } \\
\text { Combinations }\end{array}$ & Molecular Mechanisms & Molecular Targets & References \\
\hline Curcumin $+5-\mathrm{FU}$ & Resensitizing cancer cells to 5-FU effects & EMT markers & [47] \\
\hline Curcumin+Bevacizumab & Proliferation inhibition & Ki-67 & [48] \\
\hline Curcumin+Capecitabine & $\begin{array}{l}\text { Apoptosis induction } \\
\text { Proliferation inhibition }\end{array}$ & NF-kB; STAT3 & [49] \\
\hline Curcumin+Irinotecan & $\begin{array}{c}\text { Apoptosis induction } \\
\text { Resensitizing cancer cells to irinotecan effects }\end{array}$ & GSTM5; PDI; PRDX4 & [50] \\
\hline Curcumin+Irinotecan & $\begin{array}{l}\text { ER stress induction } \\
\text { Apoptosis induction } \\
\text { ROS level increase }\end{array}$ & $\mathrm{BIP} ; \mathrm{CHOP}$ & [52] \\
\hline Curcumin+Dasatinib & $\begin{array}{l}\text { Proliferation inhibition } \\
\text { Apoptosis induction }\end{array}$ & COX-2; Bcl-xL; EGFR & [53] \\
\hline Curcumin+5-FU & Resensitizing cancer cells to 5 -FU effects & NF-kB; CXCR4; MMP9 & [54] \\
\hline Hexahydrocurcumin $+5-\mathrm{FU}$ & Proliferation inhibition & COX-2 & [55] \\
\hline Resveratrol+5-FU & $\begin{array}{c}\text { Apoptosis induction } \\
\text { Resensitizing cancer cells to 5-FU effects }\end{array}$ & EMT markers & [56] \\
\hline Resveratrol+5-FU & $\begin{array}{c}\text { Proliferation inhibition } \\
\text { Reduction of migration capacity } \\
\text { Induction of DNA damage } \\
\text { Apoptosis induction }\end{array}$ & $\begin{array}{l}\text { JNK; p38 MAPK; } \\
\text { Caspase } 3\end{array}$ & [58] \\
\hline
\end{tabular}


Table 1. Cont.

\begin{tabular}{|c|c|c|c|}
\hline $\begin{array}{l}\text { Phytochemical-Drug } \\
\text { Combinations }\end{array}$ & Molecular Mechanisms & Molecular Targets & References \\
\hline EGCG+5-FU & $\begin{array}{l}\text { Proliferation inhibition } \\
\text { Resensitizing cancer cells to 5-FU effects }\end{array}$ & $\begin{array}{l}\text { GRP78; NF-kB; } \\
\text { miR-155-p; MDR1 }\end{array}$ & [59] \\
\hline EGCG+5-FU & $\begin{array}{l}\text { Resensitizing cancer cells to 5-FU effects } \\
\text { Proliferation inhibition }\end{array}$ & Caspase 3 & {$[60]$} \\
\hline EGCG+Sodium butyrate & $\begin{array}{l}\text { G2/M phase cell cycle arrest } \\
\text { Apoptosis induction }\end{array}$ & $\begin{array}{l}\text { HDAC1; DNMT1; p53; } \\
\text { p21; Survivin }\end{array}$ & {$[61]$} \\
\hline Thymoquinone+Topotecan & $\begin{array}{l}\text { Apoptosis induction } \\
\text { S phase cell cycle arrest } \\
\text { Proliferation inhibition }\end{array}$ & Caspase 3 & {$[62]$} \\
\hline Thymoquinone+DOX & Proliferation inhibition & Caspase 3 & {$[63]$} \\
\hline Thymoquinone+Irinotecan & $\begin{array}{l}\text { Autophagic cell death induction } \\
\text { Inhibition of metastasis process }\end{array}$ & $\begin{array}{l}\text { JNK; p38 MAPK; PI3K; } \\
\text { ERK 1/2; NF-kB }\end{array}$ & {$[64,65]$} \\
\hline Baicalein + DOX & $\begin{array}{l}\text { Apoptosis induction } \\
\text { DNA damage induction }\end{array}$ & Caspase 3; PCNA & {$[66]$} \\
\hline Ellagic acid $+5-\mathrm{FU}$ & $\begin{array}{l}\text { Apoptosis induction } \\
\text { Proliferation inhibition }\end{array}$ & $\begin{array}{c}\text { Bax; Bcl-2; Caspase 3; } \\
\text { PARP1 }\end{array}$ & [67] \\
\hline Ursolic acid+Capecitabine & $\begin{array}{l}\text { Inhibition of metastasis process } \\
\text { Reduction of tumor volume } \\
\text { Inhibition of pro-survival mechanisms }\end{array}$ & $\begin{array}{l}\text { NF-kB; STAT3; EGFR; } \\
\beta \text {-catenin; p53; p21; } \\
\text { MMP-9; VEGF; ICAM-1 }\end{array}$ & [68] \\
\hline $\begin{array}{l}\text { Berberine+DOX } \\
\text { Berberine+5-FU } \\
\text { Berberine+Taxol }\end{array}$ & $\begin{array}{c}\text { Apoptosis induction } \\
\text { Proliferation inhibition } \\
\text { Inhibition of pro-survival mechanisms }\end{array}$ & $\begin{array}{l}\text { AIF; IL-6; STAT3; JAK; } \\
\text { MAPK; ERK }\end{array}$ & {$[69,71,73]$} \\
\hline Tectochrysin+Cetuximab & Proliferation inhibition & $\begin{array}{l}\text { p-EGFR; COX-2; AP-1; } \\
\text { NF-kB }\end{array}$ & [74] \\
\hline Terpinen-4-ol+Cetuximab & Reduction of tumor volume & KRAS & [75] \\
\hline Casticin+TNF & Apoptosis induction & $\begin{array}{l}\text { Bcl-2; Bcl-xL; Survivin; } \\
\text { XIAP; cFLIP; DR5 }\end{array}$ & [76] \\
\hline$\beta$-sesquiphellandrene+Thalidomide & Apoptosis induction & $\begin{array}{l}\text { cFLIP; Bcl-xL; Bcl-2; } \\
\text { c-IAP1; Survivin }\end{array}$ & {$[77]$} \\
\hline$\beta$-caryophyllene+Paclitaxel & Resensitizing cancer cells to paclitaxel effects & P-gp & [78] \\
\hline$\beta$-caryophyllene+DOX & Resensitizing cancer cells to DOX effects & P-gp & [79] \\
\hline Mistletoe extract+Gemcitabine & Apoptosis induction & Caspase 3 & [82] \\
\hline Panaxadiol+Irinotecan & Apoptosis induction & Caspase 9; Caspase 3 & [83] \\
\hline
\end{tabular}

\subsection{Gastric Cancer}

Noteworthy, it has been shown in human gastric cancer cells that the use of RNA interference techniques targeting both the poly-ubiquitin genes Ubiquitin $\mathrm{B}(U B B)$ and Ubiquitin C (UBC) can remarkably decrease the proliferation rate of $23132 / 87$ primary gastric cancer cell line, through the increase of pro-apoptotic Fas protein levels, the decrease of ubiquitinated $\mathrm{H} 2 \mathrm{~A}$ histone and oncoprotein $\beta$-catenin levels, the activation of caspase 3 and the induction of the apoptotic process [91]. Interestingly, it was shown that the synergistic cytotoxic effect of the combination between curcumin and oxaliplatin or 5-FU in both in vitro and in vivo gastric cancer models was exerted through the activation of the mitochondria-dependent apoptosis, where the regulation upon caspase 9 and 3, Bcl-2, ERK1/2 as well as Wingless-related integration site (WNT) / $\beta$-catenin played a role [92]. Importantly, by activating Phosphatase and tensin homolog (PTEN), resveratrol inhibited the activity of the Rac-alpha serine/threonine-protein kinase (AKT) signaling pathway, re-sensitizing gastric cancer cells to DOX while reducing the metastasis capacity of cancer 
cells [93]. Interestingly, the amelioration of P-gp, as well as the inhibition towards the secretion of VEGF by EGCG contributed to the reversal of drug resistance against 5-FU in gastric cancer cell line SGC-7904/FU, exhibiting enhanced inhibitory effects both in in vitro and in vivo conditions [94]. In addition, the treatment of the gastric cancer cell line BGC-823 with the combination of EGCG and docetaxel showed synergistic inhibition of tumor volume in xenograft mouse models [95]. Interestingly, other than the effects on cancer growth inhibition, berberine can also overcome drug-resistance in combination with the use of clinical chemotherapeutic drugs. In fact, berberine increased the effect of heat-shock protein 90 (Hsp90) inhibitor in colon cancer cells and showed synergism with 5-FU against gastric cancer cells [73,74]. Importantly, mithramycin A associated with bevacizumab produced synergistic tumor suppression, modulating the expression of Specificity protein 1 (Sp1) and its downstream target genes, thus strongly reducing gastric cancer angiogenesis and metastasis [96]. Regarding the antitumor properties of vitamin D, Pan et al. [97] have shown that $1,25(\mathrm{OH})_{2} \mathrm{D} 3$ may promote apoptosis in the HCG-27 gastric cancer cell line. This effect appears to be the result of the up-regulation of PTEN, the tumor suppressor gene that negatively regulates the anti-apoptotic activity of Akt. The molecular pathways and molecular targets modulated by the combinations of phytochemicals and anticancer drugs in gastric cancer models are reported in Table 2.

Table 2. Gastric cancer targets.

\begin{tabular}{cccc}
\hline $\begin{array}{c}\text { Phytochemical-Drug } \\
\text { Combinations }\end{array}$ & Molecular Mechanisms & Molecular Targets & References \\
\hline Berberine+5-FU & Proliferation inhibition & Survivin; STAT3 & [72] \\
\hline $\begin{array}{c}\text { Curcumin+Oxaliplatin } \\
\text { Curcumin+5-FU }\end{array}$ & $\begin{array}{c}\text { Apoptosis induction } \\
\text { Inhibition of pro-survival mechanisms }\end{array}$ & $\begin{array}{c}\text { Caspase 9; Wnt/ } \beta \text {-catenin } \\
\text { Caspase 3; Bcl-2; ERK1/2 }\end{array}$ \\
\hline Resveratrol+DOX & $\begin{array}{c}\text { Resensitizing cancer cells to DOX effects } \\
\text { Reduction of metastasis capacity }\end{array}$ & PTEN; Akt & [93] \\
\hline EGCG+5-FU & $\begin{array}{c}\text { Proliferation inhibition } \\
\text { Resensitizing cancer cells to 5-FU effects }\end{array}$ & Ki-67; VEGF \\
\hline EGCG+Docetaxel & Reduction of tumor volume & Sp1; VEGF \\
\hline Mithramycin A+Bevacizumab & Angiogenesis inhibition & [95] \\
\hline
\end{tabular}

\subsection{Liver Cancer}

The antiproliferative effects of EGCG were studied in liver cancer both in vitro and in vivo. EGCG in combination with sorafenib inhibited cell growth both in liver cancer cell lines and xenografted mice, specifically targeting the glycolytic pathway [98]. Interestingly, it was shown that the combined treatments of DOX + EGCG and DOX + Epicatechin-3gallate (ECG) exerted significant cytotoxic effects in both BEL-7404 and BEL-7404/DOX hepatocellular carcinoma cells, through the reduction of MDR1 and HIF-1 $\alpha$ levels [99]. Furthermore, the combination of DOX and these phytochemicals reduced tumor volume in in vivo models [99]. Interestingly, a combination of EGCG and 5-FU increased the antitumor effects of 5-FU in Hep3B cells, through the modulation of Akt, COX-2, Prostaglandin E2 (PGE2) levels [100]. Moreover, it was shown that the combined treatment with Y6 (EGCGderivative) and DOX in liver cancer cells BEL-7404/DOX reduced P-gp activity, leading to a 10 fold decrease of DOX IC $\mathrm{I}_{50}$ value, and remarkably induced the apoptotic process [101].

Importantly, it was shown that the combination of bevacizumab and curcumin in an in vivo model of liver cancer was able to inhibit VEGF/Vascular endothelial growth factor receptor (VEGFR)/K-ras signaling pathways [102]. Interestingly, the curcumin-derived compound EF24 enhanced the anticancer effects of sorafenib by inhibiting MDR mechanisms through the modulation of Von Hippel-Lindau (VHL) and HIF- $1 \alpha$, in liver cancer in vitro and in vivo models [103]. Interestingly, genistein shows synergistic behavior with well-known anticancer drugs, such as adriamycin, docetaxel and tamoxifen, suggesting 
a potential role in combinational anticancer therapy [104]. Importantly, it was shown that the combination of TRAIL and genistein was able to increase the apoptosis induction rate in Hep3B liver cancer cells [105]. In addition, it was demonstrated that the use of arsenic trioxide (ATO) and genistein led to the reduction of the proliferation rate and to the induction of the apoptotic process in liver cancer cells, exerted through the inhibition of Akt and NF-kB [106]. Moreover, the combination of this phytochemical (50 $\mu \mathrm{g}$ genistein $/ \mathrm{g}$ ) with ATO reduced both tumor growth and angiogenesis in a xenograft mouse model [106].

Importantly, Wu S. et al. [107] studied the in vivo anticancer effects of a combination of resveratrol and 5-FU against Hepatoma 22 transplanted Balb/c mice xenografts, demonstrating the $\mathrm{S}$ phase arrest of Hepatoma 22 cells and the resveratrol-mediated enhancement of the anti-tumor effect of 5-FU in this xenograft model [107]. Regarding the phytochemicals of cruciferous vegetables, the anticancer effects of indole-3 carbinol were studied in combination with sorafenib in liver cancer cells HepG2 and Huh-7, showing that this association potentiated apoptosis and decreased angiogenesis process, especially in HepG2 cells, through the modulation of the levels of EMT markers and NADPH oxidase 1 (NOX1) [108]. In addition, in hepatocellular carcinoma model, an isocorydine derivative decreased cancer cell proliferation and induced apoptosis, in association with sorafenib, through the modulation of the levels of Insulin-like growth factor 2 mRNA-binding protein 3 (IGF2BP3) [109]. Importantly, cytotoxicity of DOX to HepG2 liver cancer cells was increased in combination with naringenin [110]. This study attributes the synergistic effect of this association to its ability to modulate the activity of MRPs, promote apoptosis and inhibit angiogenesis [110]. Interestingly, Shi R. et al. [111] demonstrated the in vitro and in vivo anticancer effects of a combination of cisplatin and luteolin against both liver cancer cell lines HepG2 and Hep3B and colorectal cancer cells HT29 and HCT116 and also HCT116-BALB/c nude mice xenografts. The antiproliferative effects were mediated by stabilization of tumor suppressor p53, increased JNK activation and induction of apoptosis [111]. Importantly, $\mathrm{Xu} \mathrm{Y}$ et al. [112] demonstrated the antiproliferative activity of a combination of apigenin and paclitaxel against Hep3B liver cancer cells, which was exerted through inhibition of Superoxide dismutase (SOD) activity, ROS-induced activation of caspase 2 and MMPs, increased cleavage of caspase 3 and PARP1 [112]. Regarding the phytochemical quercetin, a selective antiproliferative-boosting effect of this flavonoid on DOX was observed in hepatoma cells SMMC7721 with no significant cytotoxicity in normal liver cells L02 [113]. In particular, the addition of $20 \mu \mathrm{M}$ quercetin facilitated DOX accumulation in SMMC7721 cells and subsequently augmented cell apoptosis [113]. Interestingly, L-canavanine, a phytochemical found in several plants of the Fabaceae family, potentiated the cytotoxicity of vinblastine and paclitaxel in hepatocarcinoma cells [114]. Importantly, Zhang and collaborators examined Momordica charantia L. lectin effects, used at the dose of $0.5 \mathrm{mg} / \mathrm{Kg}$ combined with sorafenib (at the dose of $30 \mathrm{mg} / \mathrm{kg}$ ) in xenografted mice of HepG2 cells and in liver cancer cell lines. These authors documented that $M$. charantia $L$. lectin enhanced the lethal effects of sorafenib both in cell and animal models, decreasing cancer cell viability by more than 3 fold and tumor weight by about $50 \%$ [115]. The molecular pathways and molecular targets modulated by the combinations of phytochemicals and anticancer drugs in liver cancer models are reported in Table 3.

Table 3. Liver cancer targets.

\begin{tabular}{cccc}
\hline $\begin{array}{c}\text { Phytochemical-Drug } \\
\text { Combinations }\end{array}$ & Molecular Mechanisms & Molecular Targets & References \\
\hline EGCG+Sorafenib & $\begin{array}{c}\text { Proliferation inhibition } \\
\text { Inhibition of glycolytic pathway }\end{array}$ & Phosphofructokinase \\
\hline EGCG+DOX & $\begin{array}{c}\text { Proliferation inhibition } \\
\text { Reduction of tumor volume } \\
\text { ECG+DOX }\end{array}$ & Resensitizing cancer cells to DOX effects & P-gp; MDR1; HIF-1 $\alpha$ \\
\hline EGCG+5-FU & Resensitizing cancer cells to 5-FU effects & COX-2; PGE2; Akt & P-gP \\
\hline Y6 (EGCG derivative)+DOX & Resensitizing cancer cells to DOX effects & Apoptosis induction & {$[101]$} \\
\hline
\end{tabular}


Table 3. Cont.

\begin{tabular}{|c|c|c|c|}
\hline $\begin{array}{l}\text { Phytochemical-Drug } \\
\text { Combinations }\end{array}$ & Molecular Mechanisms & Molecular Targets & References \\
\hline Curcumin+Bevacizumab & $\begin{array}{l}\text { Angiogenesis inhibition } \\
\text { Reduction of tumor volume }\end{array}$ & VEGF; VEGFR; KRAS & [102] \\
\hline $\begin{array}{l}\text { EF24 (Curcumin } \\
\text { derivative)+Sorafenib }\end{array}$ & $\begin{array}{l}\text { Resensitizing cancer cells to sorafenib effects } \\
\text { Proliferation inhibition }\end{array}$ & VHL; HIF- $1 \alpha$ & [103] \\
\hline Genistein+TRAIL & $\begin{array}{c}\text { Proliferation inhibition } \\
\text { Apoptosis induction }\end{array}$ & MAPK; Caspase 8 & [105] \\
\hline Genistein+ATO & $\begin{array}{l}\text { Proliferation inhibition } \\
\text { Apoptosis induction } \\
\text { Angiogenesis inhibition }\end{array}$ & Akt; NF-kB & [106] \\
\hline Resveratrol+5-FU & $\begin{array}{c}\text { S phase cell cycle arrest } \\
\text { Resensitizing cancer cells to 5-FU effects }\end{array}$ & $\mathrm{Ki}-67$ & [107] \\
\hline Indole-3-carbinol+Sorafenib & $\begin{array}{c}\text { Apoptosis induction } \\
\text { Angiogenesis inhibition }\end{array}$ & EMT markers; NOX1 & [108] \\
\hline $\begin{array}{c}\text { Isocorydine } \\
\text { derivative+Sorafenib }\end{array}$ & $\begin{array}{l}\text { Apoptosis induction } \\
\text { Proliferation inhibition }\end{array}$ & IGF2BP3 & [109] \\
\hline Naringenin+DOX & $\begin{array}{l}\text { Apoptosis induction } \\
\text { Angiogenesis inhibition }\end{array}$ & MRPs & {$[110]$} \\
\hline Luteolin+Cisplatin & $\begin{array}{l}\text { Apoptosis induction } \\
\text { Proliferation inhibition }\end{array}$ & p53; JNK & [111] \\
\hline Apigenin+Paclitaxel & Proliferation inhibition & $\begin{array}{l}\text { SOD; Caspase 2; MMPs; } \\
\text { Caspase 3; PARP1 }\end{array}$ & [112] \\
\hline Quercetin+DOX & Resensitizing cancer cells to DOX effects & p53; Bcl-xL & [113] \\
\hline $\begin{array}{l}\text { L-canavanine+Vinblastine } \\
\text { L-canavanine+Paclitaxel }\end{array}$ & Proliferation inhibition & P-gp & {$[114]$} \\
\hline Lectin+Sorafenib & $\begin{array}{l}\text { Proliferation inhibition } \\
\text { Reduction of tumor volume }\end{array}$ & $\mathrm{Ki}-67$ & [115] \\
\hline
\end{tabular}

\subsection{Pancreatic Cancer}

Genistein enhances the efficacy of chemotherapy mainly by inhibiting survival signals and/or enhancing apoptotic signals. It was reported that genistein pretreatment inactivated NF-kB and contributed to growth inhibition and apoptosis induced by cisplatin, docetaxel, DOX or gemcitabine in various tumor cells including prostate, breast, lung, pancreatic and ovarian cancers $[116,117]$. Interestingly, genistein has been investigated as a sensitizer to gemcitabine and erlotinib in cancer cell lines and in patients with pancreatic cancer [24]. In addition, genistein was tested for its synergistic combination with gemcitabine in two murine xenografts of human pancreatic carcinoma cells (COLO357 and L3.6pl) and this treatment led to antiproliferative effects and reduction of tumor volume [117]. Furthermore, genistein restored the sensitivity to oxaliplatin in gemcitabine-resistant pancreatic cancer cells in both in vitro and in vivo models [118]. Importantly, several flavonoids including genistein and quercetin were found to downregulate MRP1 in resistant human tumor cell lines, such as pancreatic adenocarcinoma cells Panc-1, suggesting their MDR reversal potential [119].

Regarding the use of TRAIL in antitumor therapies, the combination of EGCG and TRAIL significantly diminished the proliferation of human pancreatic cancer cell line MIA PaCa-2 and increased both cleavage of procaspase-2 and apoptosis induction [120]. Importantly, the anticancer and pro-apoptotic effects of a combination of EGCG and thymoquinone in pancreatic PANC-1 cancer cell line [121] and a combination of EGCG and celecoxib in pancreatic cancer cell line Colo357 [122] have been described. Interestingly, 
the sensitization of pancreatic cancer cells for TRAIL treatment in association with benzyl isothiocyanate (extracted from cruciferous vegetables) has been demonstrated [123].

Importantly, Harikumar KB et al. [124] described the anticancer effects of a combination of resveratrol and gemcitabine against both pancreatic cancer cell lines AsPC-1, MIA PaCa-2, Panc-1, Panc-28 and also MIA-PaCa-2 cells-orthotopic mice model xenografts. The authors evidenced the downregulation of NF-kB, Bcl-2, Bcl-xL, COX-2, cyclin D1, MMP-9, VEGF, proliferation marker Ki-67, the micro-vessel density marker Clusters of differentiation 31 (CD31) and ICAM-1 [124]. Interestingly, Kallifatidis G. et al. [125] described the anticancer effects of a combination of sulforaphane and gemcitabine against both pancreatic CSCs and MIA-PaCa2 cells-xenografted BALB/c nude mice. The authors described a decrease of NF-kB activity, the downregulation of Notch homolog 1 translocation-associated (NOTCH-1) and Transcription factor p65, inhibition of aldehyde dehydrogenase 1 (ALDH1) activity, decreased proliferation of the subpopulation of CSCs, reduction of the growth of xenografts and inhibition of the relapse of drug-treated cancer cells in the mouse model [125]. Furthermore, also the phytochemical cucurbitacin B potentiated the inhibitory effects of gemcitabine in pancreatic tumors, through the modulation of the levels of Bcl-xL, Bcl-2, JAK and cellularMyelocytomatosis oncogene product (c-myc) [126].

Regarding the use of the DNA and RNA polymerase inhibitor mithramycin A, this compound was used in combination with the phytochemical betulinic acid and the anticancer drug gemcitabine in xenograft mouse models of human pancreatic cancer, where the authors observed a decrease of Sp1 and VEGF levels [127]. Moreover, it was shown that the combination of tolfenamic acid and mithramycin A exerted remarkable antitumor effects in an in vivo pancreatic cancer model through the decrease of Sp1 protein levels [128]. Interestingly, in an orthotopic pancreatic cancer mouse model obtained with PANC-1 cells, B-carboline in combination with gemcitabine reduced tumor burden and metastatic potential development [129]. Importantly, it was shown that red beetroot (Beta vulgaris) extract together with DOX induced synergistic antiproliferative effects against pancreatic PaCa-2 tumor cells [130]. The molecular pathways and molecular targets modulated by the combinations of phytochemicals and anticancer drugs in pancreatic cancer models are reported in Table 4.

Table 4. Pancreatic cancer targets.

\begin{tabular}{|c|c|c|c|}
\hline $\begin{array}{l}\text { Phytochemical-Drug } \\
\text { Combinations }\end{array}$ & Molecular Mechanisms & Molecular Targets & References \\
\hline Genistein+Erlotinib & Resensitizing cancer cells to erlotinib effects & Ubiquitin; Proteasome & [24] \\
\hline Genistein+Gemcitabine & $\begin{array}{c}\text { Proliferation inhibition } \\
\text { Reduction of tumor volume }\end{array}$ & NF-kB & {$[116,117]$} \\
\hline Genistein+Oxaliplatin & Resensitizing cancer cells to oxaliplatin effects & NF-kB; Ki-67 & {$[118]$} \\
\hline EGCG+TRAIL & $\begin{array}{l}\text { Apoptosis induction } \\
\text { Proliferation inhibition }\end{array}$ & Caspase 2; Caspase 3 & [120] \\
\hline EGCG+Celecoxib & Proliferation inhibition & IL-1 & [122] \\
\hline Benzyl isothiocyanate+TRAIL & Apoptosis induction & Caspase 8; Caspase 3 & [123] \\
\hline Resveratrol+Gemcitabine & $\begin{array}{l}\text { Proliferation inhibition } \\
\text { Angiogenesis inhibition } \\
\text { Reduction of tumor volume }\end{array}$ & $\begin{array}{l}\text { NF-kB; Bcl-2; Bcl-xL; } \\
\text { COX-2; Cyclin D1; VEGF; } \\
\text { MMP-9; Ki-67; CD31 }\end{array}$ & [124] \\
\hline Sulforaphane+Gemcitabine & $\begin{array}{l}\text { Proliferation inhibition } \\
\text { Reduction of tumor volume } \\
\text { Inhibition of CSCs growth }\end{array}$ & $\begin{array}{l}\text { NF-kB; NOTCH-1; p65; } \\
\text { ALDH1 }\end{array}$ & [125] \\
\hline Cucurbitacin B+Gemcitabine & Resensitizing cancer cells to gemcitabine effects & Bcl-xL; Bcl-2; JAK; c-myc & [126] \\
\hline Betulinic acid+ Mithramycin A & $\begin{array}{c}\text { Proliferation inhibition } \\
\text { Angiogenesis inhibition } \\
\text { Reduction of metastasis capacity }\end{array}$ & Sp1; VEGF & [127] \\
\hline
\end{tabular}


Table 4. Cont.

\begin{tabular}{cccc}
\hline $\begin{array}{c}\text { Phytochemical-Drug } \\
\text { Combinations }\end{array}$ & Molecular Mechanisms & Molecular Targets & References \\
\hline $\begin{array}{c}\text { Tolfenamic } \\
\text { acid+Mithramycin A }\end{array}$ & Reduction of tumor volume & Sp1 & Ki-67 \\
\hline B-Carboline+Gemcitabine & $\begin{array}{c}\text { Reduction of tumor volume } \\
\text { Reduction of metastasis capacity }\end{array}$ & {$[129]$} & Caspase 3 \\
\hline Red beetroot extract+DOX & Proliferation inhibition & {$[130]$} \\
\hline
\end{tabular}

\section{Phytochemicals and Anticancer Drugs Targeting Cancer Stem Cells}

CSCs represent a sub-population of tumor cells able to self-renew and to originate the different types of tumor cells which can be found in the tumor mass; specific gene mutations are required to generate CSCs from the normal stem cells [131]. The in vitro and in vivo anticancer effects of phytochemicals targeting CSCs have been described, indicating the inhibition of their MDR mechanisms and self-renewal capabilities [132]. Interestingly, it has been shown that the growth of CSCs can be inhibited by both phytochemicals (EGCG, sulforaphane) and whole natural extracts, like Sasa quelpaertensis [132]. Importantly, many phytochemicals target the Wnt ( $\beta$-catenin/T cell factor-lymphoid enhancer factor (TCFLEF)) pathway, inhibiting this pro-survival mechanism [132]. Conventional chemotherapy targets the bulk of proliferating cancer cells; as it was described for the effects of paclitaxel against several solid tumors and imatinib against chronic myelogenous leukemia; however, CSCs are resistant to these anticancer drugs [133]. An efficient antitumor therapy should acknowledge CSCs plasticity and their complete elimination. Many compounds (natural, natural-derived, synthetic) have been described as CSC-targeting and these compounds are able to target only CSCs and not normal stem cells [134-136]. Regarding CSCs targeting, Chan MM et al. [137] described the anticancer effects of several dietary phytochemicals and some repurposed drugs (Figure 2).

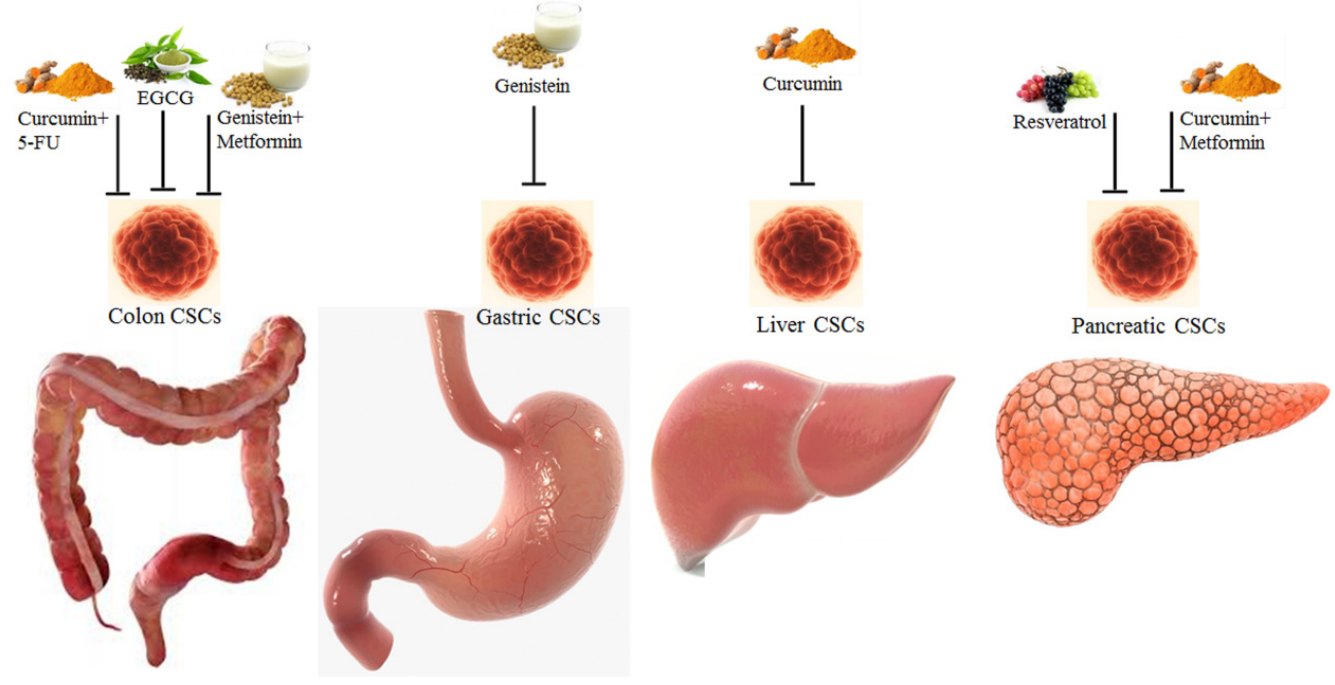

Figure 2. Phytochemicals and combinations of phytochemicals and drugs targeting the colon, gastric, liver and pancreatic CSCs [138].

Phytochemicals obtained from the diet and repurposed drugs are pleiotropic, i.e., they can target many hallmarks of cancer and molecular pathways. Interestingly, it was shown that a combination of 5-FU and curcumin decreased the growth of colorectal CSCs, evidenced by a decrease of EMT marker protein levels and through co-culture assays [139]. Importantly, Chen et al. [140] showed that EGCG inhibited the growth of spheroids obtained from colon cancer CSCs, through inhibition of the Wnt pathway, as indicated by 
a decrease in $\beta$-catenin protein levels. Furthermore, Montales et al. [141] reported that metformin and genistein targeted colon CSC spheroid formation and proliferation and their combination increased the effectiveness of 5-FU. Interestingly, Huang et al. [142] reported that genistein inhibited spheroids growth and stemness characteristics, through downregulation of Octamer-binding transcription factor 4 (Oct4) and Homeobox protein NANOG (Nanog) gene expression, and reduced tumor volume of xenografts derived from gastric cancer CSCs. Importantly, it was shown that in hepatocellular carcinoma CSCs, curcumin inhibited Sp1, invasion, EMT process and decreased tumor size in a xenograft model [143]. Regarding the CSCs of pancreatic tumors, Shankar et al. [144] indicated that resveratrol was able to inhibit the growth of pancreatic CSCs through the activation of the apoptotic process, the reduction of expression of Oct4 and Nanog and the interference with the EMT process. Interestingly, Ning et al. [145] showed that a combination of curcumin and metformin inhibited pancreatic CSCs spheroids growth.

\section{Drugs and Phytochemicals against Gastrointestinal Tumors in Clinical Practice}

Several combinations of anticancer drugs and phytochemicals have reached Phase I, II or III of clinical trials concerning gastrointestinal tumors. Interestingly, the phytochemical curcumin has been used in combination with gemcitabine and celecoxib in a phase III clinical trial against colon neoplasm, in combination with irinotecan in a phase I clinical trial against metastatic colorectal cancer and also with capecitabine against rectal cancer in a phase II clinical trial [33]. Importantly, several case-control studies and cohort studies analyzed the relationship between vitamin D intake and the risk of colorectal cancer $[146,147]$. These studies indicated that the relationship between the serum 25(OH)D3 level and colorectal cancer risk generally shows an inverse association [148-152]. Interestingly, it was demonstrated that daily administration of resveratrol (0.5-1 g/day, for 8 days) before surgery in patients with colorectal cancer could reduce the rate of tumor cell proliferation [153]. Importantly, it was shown that the phytochemicals extracted from green tea, in combination with sulindac, celecoxib, leptomycin B, DOX or cisplatin, in colon and esophageal cancer clinical trials reduced SOD and COX2 activity and showed antiproliferative effects [154]. Interestingly, a combination of mistletoe extract and commonly used chemotherapeutic drugs (including DOX), can remarkably induce the apoptotic process in tumor cells in several clinical trials [81]. Furthermore, the combination therapy based on the mistletoe extract and doxofluridine significantly increased the health status and eosinophil and leukocyte counts in gastric cancer patients when compared to untreated patients [81]. Importantly, the therapy based on SRT501 (a resveratrol oral formulation) at the dose of $5 \mathrm{~g}$ daily for two weeks induced the cleavage of caspase 3 and the induction of the apoptotic process in malignant hepatic tissues of colon cancer patients with liver metastases [155]. Interestingly, it was shown that curcumin, in combination with several anticancer drugs and phytochemicals, in clinical trials of pancreatic and colon cancer, increased the levels of tumor suppressors Bax, Bak, p53 upregulated modulator of apoptosis (PUMA) and decreased the levels of oncoproteins Bcl-2, Bcl-xL, Nuclear factor erythroid 2-related factor 2 (Nrf2), VEGF, mechanistic target of rapamycin (mTOR), NF-kB, COX-2, pSTAT3, Matrix metallopeptidase 2 (MMP2) and MMP9 [156-158]. Regarding the use of the anticancer drug gemcitabine in combination with phytochemicals, in a phase I/II clinical trial in Japan, 21 patients affected by pancreatic cancer received a therapy based on the combination of gemcitabine and curcumin ( $8 \mathrm{~g} /$ day), noteworthy, no patient had a partial response and five had a stable disease [159]. Importantly, in this phase II clinical study, the curcumin plasma levels of the treated patients ranged from 29 to $412 \mathrm{ng} / \mathrm{mL}$ [159]. Interestingly, a therapy based on the combination of gemcitabine, curcumin and Celebrex was used in a phase III clinical trial against pancreatic and colon tumors [24]. Importantly, the combined effect of gemcitabine and curcumin against pancreatic cancer was evaluated in a phase II clinical trial [160]. Pancreatic cancer patients $(n=17)$ were supplemented $8 \mathrm{~g}$ of curcumin daily for 4 weeks, in combination with gemcitabine; unluckily, this therapy was not able to significantly improve the clinical conditions of the patients [160]. Interestingly, 
genistein has been utilized also in combination with gemcitabine and erlotinib against metastatic pancreatic cancer in a recent Phase II clinical trial and the authors evidenced that the antitumor effect was exerted by the modulation of p-Akt and NF-kB levels, mediated by the combination of the phytochemical and the anticancer drugs [33].

\section{Conclusions and Future Perspectives}

Dietary phytochemicals have low or no toxicity, can be found in commonly consumed foods and have also shown potential as adjuvants in chemotherapy strategies and for chemoprevention [161,162]. Since initiation (chemoprevention) and growth (cancer chemotherapy) share common molecular pathways and mechanisms, they were applied to anticancer therapy, but the use of phytochemicals in antitumor therapies present some limitations, including poor bioavailability of phytochemicals, improper systemic delivery and patient's different genetic characteristics [33]. It is important to note that an efficient therapeutic approach is based on the accumulation of drugs and phytochemicals in the cancer site; in addition, the low bioavailability of the anticancer compounds may hinder their sufficient accumulation. For most natural molecules obtained from the diet, the hydrophobicity and the short half-life can lead to low bioavailability, reducing the efficiency of the therapies [163]. Noteworthy, it should be taken into account that many natural compounds may modulate the activity of CYP450, which is involved in the metabolism of several drugs and compounds [164]. The regulation of CYP450 activity would lead to alterations of the pharmacokinetic characteristics of phytochemicals and chemotherapeutics used in combination. In addition, the influence on the drug-metabolizing enzymes would lead to a further reduction of the phytochemical and drug bioavailability [164]. In order to solve this problem, biopolymeric nanoparticles and micelles have been used for obtaining an efficient co-delivery of drugs and phytochemicals [165]. In order to obtain the precise release of drugs specifically targeting the tumor sites, several strategies have been developed: from hydrogels to polymeric prodrugs and micelles able to self-assemble, with promising perspectives both in in vitro and in vivo cancer models [163]. Importantly, being versatile carriers for many chemotherapeutics and natural molecules, liposomes have been used to perform the co-delivery of phytochemicals and repurposed drugs in combination with anti-tumor therapeutics [163]. Interestingly, inorganic materials, like mesoporous silica nanoparticles, have been used as carriers for the delivery of conventional antitumor drugs, repurposed drugs and natural compounds [166]. In conclusion, the increased knowledge of biomarkers and molecular pathways modulated by the phytochemical and anticancer drug combinations in tumor cells and xenograft cancer models, together with the use of innovative molecular biology techniques, will remarkably improve the efficacy of these therapeutic strategies against gastrointestinal tumors and also other solid tumors in future clinical applications.

Author Contributions: E.S.S. wrote the original draft of the manuscript; E.S.S., M.G. and M.M. contributed to the review and editing of the manuscript; M.M. provided the funding acquisition. All authors have read and agreed to the published version of the manuscript.

Funding: This study was funded by the University of Urbino Carlo Bo and the University of Palermo. We acknowledge the financial support of Project BIO-D (PON MIUR, Project ARS01_00876, CUP: B32F20000270005).

Institutional Review Board Statement: Not applicable.

Informed Consent Statement: Not applicable.

Data Availability Statement: Not applicable.

Conflicts of Interest: The authors declare no conflict of interest. The funders had no role in the design of the study, in the collection, analyses, or interpretation of data, in the writing of the manuscript, or in the decision to publish the results. 


\section{References}

1. Hanahan, D.; Weinberg, R. Hallmarks of cancer: The next generation. Cell 2011, 144, 646-674. [CrossRef]

2. Salehi, B.; Zucca, P.; Sharifi-Rad, M.; Pezzani, R.; Rajabi, S.; Setzer, W.N.; Varoni, E.M.; Iriti, M.; Kobarfard, F.; Sharifi-Rad, J. Phytotherapeutics in cancer invasion and metastasis. Phytother. Res. 2018, 32, 1425-1449. [CrossRef] [PubMed]

3. Cao, H.; Xu, E.; Liu, H.; Wan, L.; Lai, M. Epithelial-mesenchymal transition in colorectal cancer metastasis: A system review. Pathol. Res. Pract. 2015, 211, 557-569. [CrossRef]

4. $\quad$ Cheng, Y.T.; Yang, C.C.; Shyur, L.F. Phytomedicine-Modulating oxidative stress and the tumor microenvironment for cancer therapy. Pharmacol. Res. 2016, 114, 128-143. [CrossRef] [PubMed]

5. Polyak, K.; Weinberg, R.A. Transitions between epithelial and mesenchymal states: Acquisition of malignant and stem cell traits. Nat. Rev. Cancer 2009, 9, 265-273. [CrossRef] [PubMed]

6. Loboda, B.; Jozkowicz, A.; Dulak, J. HIF-1 versus HIF-2-is one more important than the other? Vasc. Pharmacol. 2012, 56, $245-251$. [CrossRef]

7. Mak, P.; Leav, I.; Pursell, B.; Bae, D.; Yang, X.; Taglienti, C.A.; Gouvin, L.M.; Sharma, V.M.; Mercurio, A.M. ERbeta impedes prostate cancer EMT by destailizing HIF-1alpha and inhibiting VEGF-mediated snail nuclear localization: Implications for Gleason grading. Cancer Cell 2010, 17, 319-332. [CrossRef] [PubMed]

8. Weber, G.F. Why does cancer therapy lack effective anti-metastasis drugs? Cancer Lett. 2013, 328, 207-211. [CrossRef]

9. Zhang, H.; Xu, H.; Asby Jr, C.R.; Assaraf, Y.G.; Chen, Z.S.; Liu, H.M. Chemical molecular-based approach to overcome multidrug resistance in cancer by targeting P-glycoprotein (P-gp). Med. Res. Rev. 2021, 41, 525-555. [CrossRef] [PubMed]

10. Cairns, R.A.; Harris, I.S.; Mak, T.W. Regulation of cancer cell metabolism. Nat. Rev. Cancer 2011, 11, 85-95. [CrossRef] [PubMed]

11. Patra, S.; Nayak, R.; Patro, S.; Pradhan, B.; Sahu, B.; Behera, C.; Bhutia, S.K.; Jena, M. Chemical diversity of dietary phytochemicals and their mode of chemoprevention. Biotechnol. Rep. 2021, 30, e00633. [CrossRef]

12. Jain, A.; Madu, C.O.; Lu, Y. Phytochemicals in Chemoprevention: A Cost-effective Complementary Approach. J. Cancer 2021, 12, 3686-3700. [CrossRef] [PubMed]

13. Ma, L.; Zhang, M.M.; Zhao, R.; Wang, D.; Ma, Y.R.; Li, A. Plant Natural Products: Promising resources for Cancer Chemoprevention. Molecules 2021, 26, 933. [CrossRef]

14. Reed, J.C. Apoptosis-based therapies. Nat. Rev. Drug Discov. 2002, 1, 111-121. [CrossRef] [PubMed]

15. Di Girolamo, M.; Fabrizio, G.; Scarpa, E.S.; Di Paola, S. NAD+-dependent enzymes at the endoplasmic reticulum. Curr. Top. Med. Chem. 2013, 13, 3001-3010. [CrossRef] [PubMed]

16. Puccini, J.; Dorstyn, L.; Kumar, S. Caspase-2 as a tumor suppressor. Cell Death Differ. 2013, 20, 1133-1139. [CrossRef] [PubMed]

17. Samali, A.; Jager, R. Mechanisms of resistance to cell death pathways in cancer cells. In Pathobiology of Human Disease: A Dynamic Encyclopedia of Disease Mechanisms, 1st ed.; McManus, L.M., Mitchell, R.N., Eds.; Elsevier Inc.: Amsterdam, The Netherlands, 2014; pp. 393-402.

18. Altieri, D.C. Targeting survivin in cancer. Cancer Lett. 2013, 332, 225-228. [CrossRef]

19. Scarpa, E.S.; Emanuelli, M.; Frati, A.; Pozzi, V.; Antonini, E.; Diamantini, G.; Di Ruscio, G.; Sartini, D.; Armeni, T.; Palma, F.; et al. Betacyanins enhance vitexin-2-O-xyloside mediated inhibition of proliferation of T24 bladder cancer cells. Food Funct. 2016, 7, 4772-4780. [CrossRef]

20. Farabegoli, F.; Scarpa, E.S.; Frati, A.; Serafini, G.; Papi, A.; Spisni, E.; Antonini, E.; Benedetti, S.; Ninfali, P. Betalains increase vitexin-2-O-xyloside cytotoxicity in CaCo-2 cancer cells. Food Chem. 2017, 218, 356-364. [CrossRef] [PubMed]

21. Scarpa, E.S.; Antonini, E.; Palma, F.; Mari, M.; Ninfali, P. Antiproliferative activity of vitexin-2-O-xyloside and avenanthramides on CaCo-2 and HepG2 cancer cells occurs through apoptosis induction and reduction of pro-survival mechanisms. Eur. J. Nutr. 2018, 57, 1381-1395. [CrossRef] [PubMed]

22. Scarpa, E.S.; Mari, M.; Antonini, E.; Palma, F.; Ninfali, P. Natural and synthetic avenanthramides activate caspases 2,8,3 and downregulate hTERT, MDR1 and COX-2 genes in CaCo-2 and Hep3B cancer cells. Food Funct. 2018, 9, 2913-2921. [CrossRef]

23. Antonini, E.; Iori, R.; Ninfali, P.; Scarpa, E.S. A Combination of Moringin and Avenanthramide $2 \mathrm{f}$ Inhibits the proliferation of Hep3B Liver Cancer Cells Inducing Intrinsic and Extrinsic Apoptosis. Nutr. Cancer 2018, 70, 1159-1165. [CrossRef] [PubMed]

24. Shen, M.; Chan, T.H.; Dou, Q.P. Targeting Tumor Ubiquitin-proteasome Pathway with Polyphenols for Chemosensitization. Anticancer Agents Med. Chem. 2012, 12, 891-901. [CrossRef] [PubMed]

25. Adams, J. The proteasome: A suitable antineoplastic target. Nat. Rev. Cancer 2004, 4, 349-360. [CrossRef]

26. Jesenberger, V.; Jentsch, S. Deadly encounter: Ubiquitin meets apoptosis. Nat. Rev. Mol. Cell Biol. 2002, 3, 112-121. [CrossRef] [PubMed]

27. Voorhees, P.M.; Orlowski, R.Z. The proteasome and proteasome inhibitors in cancer therapy. Annu. Rev. Pharmacol. Toxicol. 2006, 46, 189-213. [CrossRef]

28. Longley, D.B.; Johnston, P.G. Molecular mechanisms of drug resistance. J. Pathol. 2005, 205, 275-292. [CrossRef] [PubMed]

29. Cusack, J.C., Jr.; Liu, R.; Xia, L.; Chao, T.H.; Pien, C.; Niu, W.; Palombella, V.J.; Neuteboom, S.T.; Palladino, M.A. NPI-0052 enhances tumoricidal response to conventional cancer therapy in a colon cancer model. Clin. Cancer Res. 2006, 12, 6758-6764. [CrossRef]

30. Li, B.; Dou, Q.P. Bax degradation by the ubiquitin/proteasome-dependent pathway: Involvement in tumor survival and progression. Proc. Natl. Acad. Sci. USA 2000, 97, 3850-3855. [CrossRef] 
31. Choudhuri, S.; Klaassen, C.D. Structure, function, expression, genomic organization, and single nucleotide polymorphisms of human ABCB1 (MDR1), ABCC (MRP), and ABCG2 (BCRP) efflux transporters. Int. J. Toxicol. 2006, 25, 231-259. [CrossRef]

32. Zhang, Y.; Shi, Y.; Li, X.; Du, R.; Luo, G.; Xia, L.; Du, W.; Chen, B.; Zhai, H.; Wu, K.; et al. Proteasome inhibitor MG132 reverses multidrug resistance of gastric cancer through enhancing apoptosis and inhibiting P-gp. Cancer Biol. Ther. 2008, 7, 540-546. [CrossRef] [PubMed]

33. Banudevi, S.; Swaminathan, S.; Maheswari, K.U. Pleiotropic Role of Dietary Phytochemicals in cancer: Emerging Perspectives for Combinational Therapy. Nutr. Cancer 2015, 67, 1021-1048. [CrossRef]

34. Pezzani, R.; Salehi, B.; Vitalini, S.; Iriti, M.; Zuniga, F.A.; Sharifi-Rad, J.; Martorell, M.; Martins, N. Synergistic effects of Plant Derivatives and Conventional Chemotherapeutic Agents: An Update on the Cancer Perspective. Medicina 2019, 55, 110. [CrossRef] [PubMed]

35. Yang, Q.; Nakamura, T.; Seto, M.; Miyagawa, M.; Xu, W.; Zhu, B.; Munemasa, S.; Murata, Y.; Nakamura, Y. A multidrug resistance-associated protein inhibitor is a potential enhancer of the benzyl isothiocyanate-induced apoptosis induction in human colorectal cancer cells. J. Biochem. Mol. Toxicol. 2021, 35, e22791. [CrossRef]

36. Ninfali, P.; Antonini, E.; Frati, A.; Scarpa, E.S. C-Glycosyl Flavonoids from Beta vulgaris Cicla and Betalains from Beta vulgaris rubra: Antioxidant, Anticancer and Antiinflammatory Activities-A Review. Phytother Res. 2017, 31, 871-884. [CrossRef]

37. Kumar, G.; Mittal, S.; Sak, K.; Tuli, H.S. Molecular mechanisms underlying chemopreventive potential of curcumin: Current challenges and future perspectives. Life Sci. 2016, 148, 313-328. [CrossRef]

38. Rejinold, N.S.; Yoo, J.; Jon, S.; Kim, Y.C. Curcumin as a novel nanocarrier system for doxorubicin delivery to MDR cancer cells: In vitro and in vivo evaluation. ACS Appl. Mater. Interfaces 2018, 10, 28458-28470. [CrossRef]

39. Muddineti, O.S.; Kumari, P.; Ghosh, B.; Torchilin, V.P.; Biswas, S. D-Alpha-tocopheryl succinate/phosphatidyl ethanolamine conjugated amphiphilic polymer-based nanomicelle system for the efficient delivery of curcumin and to overcome multiple drug resistance in cancer. ACS Appl. Mater. Interfaces 2017, 9, 16779-16793. [CrossRef]

40. Barros, A.S.; Costa, E.C.; Nunes, A.S.; de Melo-Diogo, D.; Correia, I.J. Comparative study of the therapeutic effect of Doxorubicin and Resveratrol combination on 2D and 3D (spheroids) cell culture models. Int. J. Pharm. 2018, 551, 76-83. [CrossRef] [PubMed]

41. Qazi, A.; Pal, J.; Maitah, M.; Fulciniti, M.; Pelluru, D.; Nanjappa, P.; Lee, S.; Batchu, R.B.; Prasad, M.; Bryant, C.S.; et al. Anticancer activity of a broccoli derivative, sulforaphane, in barrett adenocarcinoma: Potential use in chemoprevention and as adjuvant in chemotherapy. Transl. Oncol. 2010, 3, 389-399. [CrossRef]

42. Bhardwaj, R.K.; Glaeser, H.; Becquemont, L.; Klotz, U.; Gupta, S.K.; Fromm, M.F. Piperine, a major constituent of black peeper, inhibits human P-glycoprotein and CYP3A4. Pharmacol. Exp. Ther. 2002, 302, 645-650. [CrossRef] [PubMed]

43. Makhov, P.; Golovine, K.; Canter, D.; Kutikov, A.; Simhan, J.; Corlew, M.M.; Uzzo, R.G.; Kolenko, M. Co-administration of piperine and docetaxel results in improved anti-tumor efficacy via inhibition of CYP3A4 activity. Prostate 2012, 72, 661-667. [CrossRef] [PubMed]

44. Bezerra, D.P.; de Castro, F.O.; Alves, A.P.N.N.; Pessoa, C.; de Moraes, M.O.; Silveira, E.R.; Lima, M.A.S.; Elmiro, F.J.M.; de Alencar, N.M.N.; Mesquita, R.O.; et al. In vitro and in vivo antitumor effect of 5-FU combined with piplartine and piperine. J. Appl. Toxicol. 2008, 28, 156-163. [CrossRef] [PubMed]

45. Najar, I.A.; Sharma, S.C.; Singh, G.D.; Koul, S.; Gupta, P.N.; Javed, S.; Johri, R.K. Involvement of P-glycoprotein and CYP3A4 in the enhancement of etoposide bioavailability by a piperine analogue. Chem.-Biol. Interact. 2011, 190, 84-90. [CrossRef] [PubMed]

46. Goel, A.; Aggarwal, B.B. Curcumin, the golden spice from Indian saffron, is a chemosensitizer and radiosensitizer for tumors and chemoprotector and radioprotector for normal organs. Nutr. Cancer 2010, 62, 919-930. [CrossRef]

47. Toden, S.; Okugawa, Y.; Jascur, T.; Wodarz, D.; Komarova, N.L.; Buhrmann, C.; Shakibaei, M.; Boland, C.R.; Goel, A. Curcumin mediates chemosensitization to 5-fluorouracil through miRNA-induced suppression of epithelial-to-mesenchymal transition in chemoresistant colorectal cancer. Carcinogenesis 2015, 36, 355-367. [CrossRef]

48. Yue, G.G.; Kwok, H.F.; Lee, J.K.; Jiang, L.; Wong, E.C.; Gao, S.; Wong, H.L.; Li, L.; Chan, K.M.; Leung, P.C.; et al. Combined therapy using bevacizumab and turmeric ethanolic extract (with absorbable curcumin) exhibited beneficial efficacy in colon cancer mice. Pharmacol. Res. 2016, 11, 43-57. [CrossRef]

49. Kim, J.H.; Gupta, S.C.; Park, B.; Yadav, V.R.; Aggarwal, B.B. Turmeric (Curcuma longa) inhibits inflammatory nuclear factor (NF)-kappaB and NF-kappaB-regulated gene products and induces death receptors leading to suppressed proliferation, induced chemosensitization, and suppressed osteoclastogenesis. Mol. Nutr. Food Res. 2012, 56, 454-465. [CrossRef] [PubMed]

50. Zhu, D.J.; Chen, X.W.; Wang, J.Z.; Ju, Y.L.; Ou Yang, M.Z.; Zhang, W.J. Proteomic analysis identifies proteins associated with curcumin-enhancing efficacy of irinotecan-induced apoptosis of colorectal cancer LOVO cell. Int. J. Clin. Exp. Pathol. 2014, 7, 1-15. [PubMed]

51. Neerati, P.; Sudhakar, Y.A.; Kanwar, J.R. Curcumin regulates colon cancer by inhibiting P-glycoprotein in in-situ cancerous colon perfusion rat model. J. Cancer Sci. Ther. 2013, 5, 313-319. [PubMed]

52. Huang, Y.F.; Zhu, D.J.; Chen, X.W.; Chen, Q.K.; Luo, Z.T.; Liu, C.C.; Wang, G.X.; Zhang, W.J.; Liao, N.Z. Curcumin enhances the effects of irinotecan on colorectal cancer cells through the generation of reactive oxygen species and activation of the endoplasmic reticulum stress pathway. Oncotarget 2017, 8, 40264-40275. [CrossRef] [PubMed]

53. Nautiyal, J.; Banerjee, S.; Kanwar, S.S.; Yu, Y.; Patel, B.B.; Sarkar, F.H.; Majumdar, A.P.N. Curcumin enhances dasatinib-induced inhibition of growth and transformation of colon cancer cells. Int. J. Cancer 2011, 128, 951-961. [CrossRef] 
54. Shakibaei, M.; Kraehe, P.; Popper, B.; Shayan, P.; Goel, A.; Buhrmann, C. Curcumin potentiates antitumor activity of 5-fluorouracil in a 3D alginate tumor microenvironment of colorectal cancer. BMC Cancer 2015, 15, 250-264. [CrossRef]

55. Srimuangwong, K.; Tocharus, C.; Chintana, P.Y.; Suksamrarn, A.; Tocharus, J. Hexahydrocurcumin enhances inhibitory effect of 5-fluorouracil on HT-29 human colon cancer cells. World J. Gastroenterol. 2011, 18, 2383-2389. [CrossRef]

56. Buhrmann, C.; Shayan, P.; Kraehe, P.; Popper, B.; Goel, A.; Shakibaei, M. Resveratrol induces chemosensitization to 5-fluorouracil through up-regulation of intercellular junctions, epithelial-to-mesenchymal transition and apoptosis in colorectal cancer. Biochem. Pharmacol. 2015, 98, 51-68. [CrossRef]

57. Erdem, T.; Bayindir, T.; Filiz, A.; Iraz, M.; Selimoglu, E. The effect of resveratrol on the prevention of cisplatin ototoxicity. Eur. Arch. Otorhinolaryngol. 2012, 269, 2185-2188. [CrossRef]

58. Mohapatra, P.; Preet, R.; Choudhuri, M.; Choudhuri, T.; Kundu, C.N. 5-fluorouracil increases the chemopreventive potentials of resveratrol through DNA damage and MAPK signaling pathway in human colorectal cancer cells. Oncol. Res. 2011, 19, 311-321. [CrossRef]

59. La, X.; Zhang, L.; Li, Z.; Li, H.; Yang, Y. (-)-Epigallocatechin gallate (EGCG) enhances the sensitivity of colorectal cancer cells to 5-FU by inhibiting GRP78/NF-kappaB/miR-155-5p/MDR1 pathway. J. Agric. Food Chem. 2019, 67, 2510-2518. [CrossRef]

60. Wang, R.; Huang, J.; Chen, J.; Yang, M.; Wang, H.; Qiao, H.; Chen, Z.; Hu, L.; Di, L.; Li, J. Enhanced anti-colon cancer efficacy of 5-fluorouracil by epigallocatechin-3-gallate co-loaded in wheat germ agglutinin-conjugated nanoparticles. Nanomedicine 2019, 21, 102068. [CrossRef]

61. Saldanha, S.N.; Kala, R.; Tollefsbol, T.O. Molecular mechanisms for inhibition of colon cancer cells by combined epigeneticmodulating epigallocatechin gallate and sodium butyrate. Exp. Cell Res. 2014, 324, 40-53. [CrossRef]

62. Khalife, R.; Hodroj, M.H.; Fakhoury, R.; Rizk, S. Thymoquinone from nigella sativa seeds promotes the antitumor activity of noncytotoxic doses of topotecan in human colorectal cancer cells in vitro. Planta Med. 2016, 82, 312-321. [CrossRef] [PubMed]

63. Effenberger-Neidnicht, K.; Schobert, R. Combinatorial effects of thymoquinone on the anti-cancer activity of doxorubicin. Cancer Chemother. Pharmacol. 2011, 67, 867-874. [CrossRef] [PubMed]

64. Chen, M.C.; Lee, N.H.; Hsu, H.H.; Ho, T.J.; Tu, C.C.; Hsieh, D.J.; Lin, Y.M.; Chen, L.M.; Kuo, W.W.; Huang, C.Y. Thymoquinone induces caspase-independent, autophagic cell death in CPT-11-resistant lovo cancer via mitochondrial dysfunction and activation of JNK and p38. J. Agric. Food Chem. 2015, 63, 1540-1546. [CrossRef] [PubMed]

65. Chen, M.C.; Lee, N.H.; Hsu, H.H.; Ho, T.J.; Tu, C.C.; Chen, R.J.; Lin, Y.M.; Viswanadha, V.P.; Kuo, W.W.; Huang, C.Y. Inhibition of nf-kappab and metastasis in irinotecan (CPT-11)-resistant lovo colon cancer cells by thymoquinone via JNK and p38. Environ. Toxicol. 2017, 32, 669-678. [CrossRef] [PubMed]

66. Palko-Labuz, A.; Sroda-Pomianek, K.; Wesolowska, O.; Kostrzewa-Suslow, E.; Uryga, A.; Michalak, K. MDR reversal and pro-apoptotic effects of statins and statins combined with flavonoids in colon cancer cells. Biomed. Pharm. 2019, 109, 1511-1522. [CrossRef] [PubMed]

67. Kao, T.; Chung, Y.; Hou, Y.; Tsai, Y.W.; Chen, C.H.; Chang, H.P.; Chou, J.L.; Hsu, C.P. Effects of ellagic acid on chemosensitivity to 5-fluorouracil in colorectal carcinoma cells. Anticancer Res. 2012, 32, 4413-4418. [PubMed]

68. Prasad, S.; Yadav, V.R.; Sung, B.; Reuter, S.; Kannappan, R.; Deorukhkar, A.; Diagaradjane, P.; Wei, C.; Baladandayuthapani, V.; Krishnan, S.; et al. Ursolic acid inhibits growth and metastasis of human colorectal cancer in an orthotopic nude mouse model by targeting multiple cell signaling pathways: Chemosensitization with capecitabine. Clin. Cancer Res. 2012, 18, $4942-4953$. [CrossRef] [PubMed]

69. Wang, L.; Liu, L.; Shi, Y.; Cao, H.; Chaturvedi, R.; Calcutt, M.W.; Hu, T.; Ren, X.; Wilson, K.T.; Polk, D.B.; et al. Berberine induces caspase-independent cell death in colon tumor cells through activation of apoptosis-inducing factor. PLoS ONE 2012, 7, e36418. [CrossRef]

70. Park, S.H.; Sung, J.H.; Kim, E.J.; Chung, N. Berberine induces apoptosis via ROS generation in PANC-1 and MIA-PaCa2 pancreatic cell lines. Braz. J. Med. Biol. Res. 2015, 48, 111-119. [CrossRef] [PubMed]

71. Yu, Y.N.; Yu, T.C.; Zhao, H.J.; Sun, T.T.; Chen, H.M.; Chen, H.Y.; An, H.F.; Weng, Y.R.; Yu, J.; Li, M.; et al. Berberine may rescue Fusobacterium nucleatum-induced colorectal tumorigenesis by modulating the tumor microenvironment. Oncotarget 2015, 6 , 32013-32026. [CrossRef]

72. Pandey, A.; Vishnoi, K.; Mahata, S.; Tripathi, S.C.; Misra, S.P.; Misra, V.; Mehrotra, R.; Dwivedi, M.; Bharti, A.C. Berberine and curcumin taget survivin and STAT3 in gastric cancer cells and synergize actions of standard chemotherapeutic 5-fluorouracil. Nutr. Cancer 2015, 67, 1293-1304. [CrossRef] [PubMed]

73. Su, Y.H.; Tang, W.C.; Cheng, Y.W.; Sia, P.; Huang, C.C.; Lee, Y.C.; Jiang, H.Y.; Wu, M.H.; Lai, I.L.; Lee, J.W.; et al. Targeting of multiple oncogenic signaling pathways by Hsp90 inhibitor alone or in combination with berberine for treatment of colorectal cancer. Biochim. Biophys. Acta 2015, 1853, 2261-2272. [CrossRef] [PubMed]

74. Park, M.H.; Hong, J.E.; Hwang, C.J.; Choi, M.; Choi, J.S.; An, Y.J.; Son, D.J.; Hong, J.T. Synergistic inhibitory effect of cetuximab and tectochrysin on human colon cell growth via inhibition of EGFR signal. Arch. Pharmacal Res. 2016, 39, 721-729. [CrossRef]

75. Shapira, S.; Pleban, S.; Kazanov, D.; Tirosh, P.; Arber, N. Terpinen-4-ol: A novel and promising therapeutic agent for human gastrointestinal cancers. PLoS ONE 2016, 11, e0156540. [CrossRef]

76. Tang, S.Y.; Zhong, M.Z.; Yuan, G.J.; Hou, S.P.; Yin, L.L.; Jiang, H.; Yu, Z.Y. Casticin, a flavonoid, potentiates TRAIL-induced apoptosis through modulation of anti-apoptotic proteins and death receptor 5 in colon cancer cells. Oncol. Rep. 2013, 29, 474-480. [CrossRef] [PubMed] 
77. Tyagi, A.K.; Prasad, S.; Yuan, W.; Li, S.; Aggarwal, B.B. Identification of a novel compound (beta-sesquiphellandrene) from turmeric (Curcuma longa) with anticancer potential: Comparison with curcumin. Investig. New Drugs 2015, 33, 1175-1186. [CrossRef] [PubMed]

78. Legault, J.; Pichette, A. Potentiating effect of beta-caryophyllene on anticancer activity of alpha-humulene, isocaryophyllene and paclitaxel. J. Pharm. Pharmacol. 2007, 59, 1643-1647. [CrossRef] [PubMed]

79. Ambroz, M.; Matouskova, P.; Skarka, A.; Zajdlova, M.; Zakova, K.; Skalova, L. The effects of selected sesquiterpenes from myrica rubra essential oil on the efficacy of doxorubicin in sensitive and resistant cancer cell line. Molecules 2017, 22, 1021. [CrossRef] [PubMed]

80. Yang, X.; Jiang, S.; Liu, Y.; Zhang, P.; Xie, S.; Wang, G. Recombinant VAA-1 from Viscum album induces apoptotic cell death of hepatocellular carcinoma SMMC7721 cells. Molecules 2012, 17, 11435-11446. [CrossRef]

81. Kim, K.C.; Yook, J.H.; Eisenbraun, J.; Kim, B.S.; Huber, R. Quality of life, immunomodulation and safety of adjuvant mistletoe treatment in patients with gastric carcinoma-a randomized, controlled pilot study. BMC Complement. Altern. Med. 2012, 12, 172-178. [CrossRef] [PubMed]

82. Mansky, P.J.; Wallerstedt, D.B.; Sannes, T.S.; Stagl, J.; Johnson, L.L.; Blackman, M.R.; Grem, J.L.; Swain, S.M.; Monahan, B.P. NCCAM/NCI phase 1 study of mistletoe extract and gemcitabine in patients with advanced solid tumors. Evid.-Based Complement. Altern. Med. 2013, 2013, 964592. [CrossRef] [PubMed]

83. Du, G.J.; Wang, C.Z.; Zhang, Z.Y.; Wen, X.D.; Somogyi, J.; Calway, T.; He, T.C.; Du, W.; Yuan, C.S. Caspase-mediated pro-apoptotic interaction of panaxadiol and irinotecan in human colorectal cancer cells. J. Pharm. Pharmacol. 2012, 64, 727-734. [CrossRef] [PubMed]

84. Giammanco, M.; Di Majo, D.; La Guardia, M.; Aiello, S.; Crescimanno, M.; Flandina, C.; Tumminello, F.M.; Leto, G. Vitamin D in cancer chemoprevention. Pharm. Biol. 2015, 53, 1399-1434. [CrossRef] [PubMed]

85. Bettoun, D.J.; Buck, D.W.; Lu, J.; Khalifa, B.; Chin, W.W.; Nagpal, S. A vitamin D receptor-Ser/Thr phosphatase-p70 S6 kinase complex and modulation of its enzymatic activities by the ligand. J. Biol. Chem. 2002, 277, 24847-24850. [CrossRef] [PubMed]

86. Palmer, H.G.; Gonzalez-Sancho, J.M.; Espada, J.; Berciano, M.T.; Puig, I.; Baulida, J.; Quintanilla, M.; Cano, A.; de Herreros, A.G.; Lafarga, M.; et al. Vitamin $\mathrm{D}(3)$ promotes the differentiation of colon carcinoma cells by the induction of E-cadherin and the inhibition of beta-catenin signaling. J. Cell Biol. 2001, 154, 369-387. [CrossRef]

87. Pendas-Franco, N.; Aguilera, O.; Pereira, F.; Gonzalez-Sancho, J.M.; Munoz, A. Vitamin D and Wnt/beta-catenin pathway in colon cancer: Role and regulation of DICKKOPF genes. Anticancer Res. 2008, 28, 2613-2623.

88. Pereira, F.; Larriba, M.J.; Munoz, A. Vitamin D and colon cancer. Endocr. Relat Cancer 2012, 19, 51-71. [CrossRef] [PubMed]

89. Gaschott, T.; Steinmeyer, A.; Steinhilber, D.; Stein, J. ZK156718 a low calcemic, antiproliferative, and prodifferentiating vitamin D analog. Biochem. Biophys. Res. Commun. 2002, 290, 504-509. [CrossRef]

90. Meeker, S.; Seamons, A.; Paik, J.; Treuting, P.M.; Brabb, T.; Grady, W.M.; Maggio-Price, L. Increased dietary Vitamin D suppresses MAPK signaling, colitis, and colon cancer. Cancer Res. 2014, 74, 4398-4408. [CrossRef]

91. Scarpa, E.S.; Tasini, F.; Crinelli, R.; Ceccarini, C.; Magnani, M.; Bianchi, M. The Ubiquitin Gene Expression Pattern and Sensitivity to UBB and UBC Knockdown Differentiate Primary 23132/87 and Metastatic MKN45 Gastric Cancer Cells. Int. J. Mol. Sci. 2020, 21, 5435. [CrossRef]

92. Zhou, X.; Wang, W.M.; Li, P.H.; Zheng, Z.Q.; Tu, Y.Y.; Zhang, Y.; You, T. Curcumin enhances the effects of 5-fluorouracil and oxaliplatin in inducing gastric cancer cell apoptosis both in vitro and in vivo. Oncol. Res. 2015, 23, 29-34. [CrossRef] [PubMed]

93. Xu, J.; Liu, D.; Niu, H.; Zhu, G.; Xu, Y.; Ye, D.; Li, J.; Zhang, Q. Resveratrol reverses Doxorubicin resistance by inhibiting epithelial-mesenchymal transition (EMT) through modulating PTEN/Akt signaling pathway in gastric cancer. J. Exp. Clin. Cancer Res. 2017, 36, 19-32. [CrossRef]

94. Tang, H.S.; Zeng, L.S.; Wang, J.H.; Zhang, X.L.; Ruan, Q.; Wang, J.; Cui, S.Z.; Yang, D.H. Reversal of 5-fluorouracil resistance by EGCG is mediated by inactivation of TFAP2A/VEGF signaling pathway and downregulation of MDR-1 and P-gp expression in gastric cancer. Oncotarget 2017, 8, 82842-82853. [CrossRef]

95. Wu, H.; Xin, Y.; Xiao, Y.; Zhao, J. Low-dose docetaxel combined with (-)-epigallocatechin-3-gallate inhibits angiogenesis and tumor growth in nude mice with gastric cancer xenografts. Cancer Biother. Radiopharm. 2012, 27, 204-209. [CrossRef] [PubMed]

96. Wang, L.; Guan, X.; Zhang, J.; Jia, Z.; Wei, D.; Li, Q.; Yao, J.; Xie, K. Targeted inhibition of Sp1-mediated transcription for antiangiogenic therapy of metastatic human gastric cancer in orthotopic nude mouse models. Int. J. Oncol. 2008, 33, 161-167. [CrossRef] [PubMed]

97. Pan, L.; Matloob, A.F.; Du, J.; Pan, H.; Dong, Z.; Zhao, J.; Feng, Y.; Zhong, Y.; Huang, B.; Lu, J. Vitamin D stimulates apoptosis in gastric cancer cells in synergy with trichostatin A/sodium butyrate-induced and 5-aza-2'-deoxycitidine-induced PTEN upregulation. FEBS J. 2010, 277, 989-999. [CrossRef]

98. Li, S.; Wu, L.; Feng, J.; Li, J.; Liu, T.; Zhang, R.; Xu, S.; Cheng, K.; Zhou, Y.; Zhou, S.; et al. In vitro and in vivo study of epigallocatechin-3-gallate-induced apoptosis in aerobic glycolytic hepatocellular carcinoma cells involving inhibition of phosphofructokinase activity. Sci. Rep. 2016, 6, 28479-28495. [CrossRef] [PubMed]

99. Liang, G.; Tang, A.; Lin, X.; Li, L.; Zhang, S.; Huang, Z.; Tang, H.; Li, Q.Q. Green tea catechins augment the antitumor activity of doxorubicin in an in vivo mouse model for chemoresistant liver cancer. Int. J. Oncol. 2010, 37, 111-123. [PubMed] 
100. Yang, X.W.; Wang, X.L.; Cao, L.Q.; Jiang, X.F.; Peng, H.P.; Lin, S.M.; Xue, P.; Chen, D. Green tea polyphenol epigallocatechin-3gallate enhances 5-fluorouracil-induced cell growth inhibition of hepatocellular carcinoma cells. Hepatol. Res. 2012, 45, 494-501. [CrossRef]

101. Wen, Y.; Zhao, R.Q.; Zhang, Y.K.; Gupta, P.; Fu, L.X.; Tang, A.Z.; Liu, B.M.; Chen, Z.S.; Yang, D.H.; Liang, G. Effect of Y6, an epigallocatechin gallate derivative on reversing doxorubicin drug resistance in human hepatocellular carcinoma cells. Oncotarget 2017, 8, 29760-29770. [CrossRef]

102. Gao, J.Z.; Du, J.L.; Wang, Y.L.; Li, J.; Wei, L.X.; Guo, M.Z. Synergistic effects of curcumin and bevacizumab on cell signaling pathways in hepatocellular carcinoma. Oncol. Lett. 2015, 9, 295-299. [CrossRef]

103. Liang, Y.; Zheng, T.; Song, R.; Wang, J.; Yin, D.; Wang, L.; Liu, H.; Tian, L.; Fang, X.; Meng, X.; et al. Hypoxia-mediated sorafenib resistance can be overcome by EF24 through Von Hippel-Lindau tumor suppressor-dependent HIF-1alpha inhibition in hepatocellular carcinoma. Hepatology 2013, 57, 1847-1857. [CrossRef] [PubMed]

104. Spagnuolo, C.; Russo, G.L.; Orhan, I.E.; Habtemariam, S.; Daglia, M.; Sureda, A.; Nabavi, S.F.; Devi, K.P.; Loizzo, M.R.; Tundis, R.; et al. Genistein and Cancer: Current Status, Challenges, and Future Directions. Adv. Nutr. 2015, 6, 408-419. [CrossRef] [PubMed]

105. Jin, C.Y.; Park, C.; Moon, S.K.; Kim, G.Y.; Kwon, T.K.; Lee, S.J.; Kim, W.J.; Choi, Y.H. Genistein sensitizes human hepatocellular carcinoma cells to TRAIL-mediated apoptosis by enhancing Bid cleavage. Anticancer Drugs 2009, 20, 713-722. [CrossRef] [PubMed]

106. Ma, Y.; Wang, J.; Liu, L.; Zhu, H.; Chen, X.; Pan, S.; Sun, X.; Jiang, H. Genistein potentiates the effect of arsenic trioxide against human hepatocellular carcinoma: Role of Akt and nuclear factor-kappa B. Cancer Lett. 2011, 301, 75-84. [CrossRef]

107. Wu, S.; Sun, Z.; Yu, L.; Meng, K.; Qin, X.L.; Pan, C.E. Effect of resveratrol and in combination with 5-FU on murine liver cancer. World J. Gastroenterol. 2004, 10, 3048-3052. [CrossRef] [PubMed]

108. Abdelmageed, M.M.; El-Naga, R.N.; El-Demerdash, E.; Elmazar, M.M. Indole-3-carbinol enhances sorafenib cytotoxicity in hepatocellular carcinoma cells: A mechanistic study. Sci. Rep. 2016, 6, 32733-32744. [CrossRef]

109. Li, M.; Zhang, L.; Ge, C.; Chen, L.; Fang, T.; Li, H.; Tian, H.; Liu, J.; Chen, T.; Jiang, G.; et al. An isocorydine derivative (d-ICD) inhibits drug resistance by downregulating IGF2BP3 expression in hepatocellular carcinoma. Oncotarget 2015, 6, 25149-25160. [CrossRef]

110. Zhang, F.Y.; Du, G.J.; Zhang, L.; Zhang, C.L.; Lu, W.L.; Liang, W. Naringenin enhances the anti-tumor effect of doxorubicin through selectively inhibiting the activity of multidrug resistance-associated proteins but not P-glycoprotein. Pharm. Res. 2006, 26, 914-925. [CrossRef] [PubMed]

111. Shi, R.; Huang, Q.; Zhu, X.; Ong, Y.B.; Zhao, B.; Lu, J.; Ong, C.N.; Shen, H.M. Luteolin sensitizes the anticancer effect of cisplatin via c-Jun NH2-terminal kinase-mediated p53 phosphorylation and stabilization. Mol. Cancer Ther. 2007, 6, 1338-1347. [CrossRef] [PubMed]

112. Xu, Y.; Xin, Y.; Diao, Y.; Lu, C.; Fu, J.; Luo, L.; Yin, Z. Synergistic effects of apigenin and paclitaxel on apoptosis of cancer cells. PLoS ONE 2011, 6, e29169. [CrossRef]

113. Wang, G.Y.; Zhang, J.W.; Liu, L.Y.; Sharma, S.; Dong, Q.H. Quercetin potentiates doxorubicin mediated antitumor effects against liver cancer through p53/Bcl-xl. PLoS ONE 2012, 7, e51764. [CrossRef] [PubMed]

114. Nurcahyanti, A.D.; Wink, M. Cytotoxic potentiation of vinblastine and paclitaxel by l-canavanine in human cervical cancer and hepatocellular carcinoma cells. Phytomedicine 2015, 22, 1232-1237. [CrossRef] [PubMed]

115. Zhang, C.Z.; Fang, E.F.; Zhang, H.T.; Liu, L.L.; Yun, J.P. Momordica charantia lectin exhibits antitumor activity towards hepatocellular carcinoma. Investig. New Drugs 2015, 33, 1-11. [CrossRef] [PubMed]

116. Li, Y.; Ahmed, F.; Ali, S.; Philip, P.A.; Kucuk, O.; Sarkar, F.H. Inactivation of nuclear factor kappaB by soy isoflavone genistein contributes to increased apoptosis induced by chemotherapeutic agents in human cancer cells. Cancer Res. 2005, 65, 6934-6942. [CrossRef] [PubMed]

117. Banerjee, S.; Zhang, Y.; Ali, S.; Bhuiyan, M.; Wang, Z.; Chiao, P.J.; Philip, P.A.; Abbruzzese, J.; Sarkar, F.H. Molecular evidence for increased antitumor activity of gemcitabine by genistein in vitro and in vivo using an orthotopic model of pancreatic cancer. Cancer Res. 2005, 65, 9064-9072. [CrossRef] [PubMed]

118. Banerjee, S.; Kong, D.; Azmi, A.S.; Wang, Z.; Ahmad, A.; Sethi, S.; Sarkar, F.H. Restoring sensitivity to oxaliplatin by a novel approach in gemcitabine-resistant pancreatic cancer cells in vitro and in vivo. Int. J. Cancer 2011, 128, 1240-1250. [CrossRef]

119. Miron, A.; Aprotosaie, A.C.; Trifan, A.; Xiao, J. Flavonoids as modulators of metabolic enzymes and drug transporters. Ann. N. Y. Acad. Sci. 2017, 1398, 152-167. [CrossRef]

120. Basu, H.; Haldar, S. Combinatorial effect of epigallocatechin-3-gallate and TRAIL on pancreatic cancer cell death. Int. J. Oncol. 2009, 34, 281-286. [CrossRef]

121. Tan, M.; Norwood, A.; May, M.; Tucci, M.; Benghuzzi, H. Effects of (-)-epigallocatechin gallate and thymoquinone on proliferation of a PANC-1 cell line in culture. Biomed. Sci. Instrum 2006, 42, 363-371.

122. Hardtner, C.; Multhoff, G.; Falk, W.; Radons, J. (-)-Epigallocatechin-3-gallate, a green tea-derived catechin, synergizes with celecoxib to inhibit IL-1-induced tumorigenic mediators by human pancreatic adenocarcinoma cells Colo357. Eur. J. Pharmacol. 2012, 684, 36-43. [CrossRef] [PubMed]

123. Wicker, C.A.; Sahu, R.P.; Kulkarni-Datar, K.; Srivastava, S.J.; Brown, T.L. BITC sensitizes pancreatic adenocarcinoma to TRAILinduced apoptosis. Cancer Growth Metastasis 2010, 2009, 45-55. [CrossRef] 
124. Harikumar, K.B.; Kunnumakkara, A.B.; Sethi, G.; Diagaradjane, P.; Anand, P.; Pandey, M.K.; Gelovani, J.; Krishnan, S.; Guha, S.; Aggarwal, B.B. Resveratrol, a multi-targeted agent, can enhance antitumor activity of gemcitabine in vitro and in orthotopic mouse model of human pancreatic cancer. Int. J. Cancer 2010, 127, 257-268. [PubMed]

125. Kallifatidis, G.; Labsch, S.; Rausch, V.; Mattern, J.; Gladikich, J.; Moldenhauer, G.; Buchler, M.W.; Salnikov, A.V.; Herr, I. Sulforaphane increases drug-mediated cytotoxicity toward cancer stem-like cells of pancreas and prostate. Mol. Ther. 2011, 19, 188-195. [CrossRef] [PubMed]

126. Iwanski, G.B.; Lee, D.H.; En-Gal, S.; Doan, N.B.; Castor, B.; Vogt, M.; Toh, M.; Bokemeyer, C.; Said, J.W.; Thoennissen, N.H.; et al. Cucurbitacin $\mathrm{B}$, a novel in vivo potentiator of gemcitabine with low toxicity in the treatment of pancreatic cancer. Br. J. Pharmacol. 2010, 160, 998-1007. [CrossRef]

127. Gao, Y.; Jia, Z.; Kong, X.; Li, Q.; Chang, D.Z.; Wei, D.; Le, X.; Suyun, H.; Huang, S.; Wang, L.; et al. Combining betulinic acid and mithramycin A effectively suppresses pancreatic cancer by inhibiting proliferation, invasion and angiogenesis. Cancer Res. 2011, 71, 5182-5193. [CrossRef] [PubMed]

128. Jia, Z.; Gao, Y.; Wang, L.; Li, Q.; Zhang, J.; Le, X.; Wei, D.; Yao, J.C.; Chang, D.Z.; Huang, S.; et al. Combined treatment of pancreatic cancer with mithramycin A and tolfenamic acid promotes Sp1 degradation and synergistic antitumor activity. Cancer Res. 2010, 70, 1111-1119. [CrossRef]

129. Yu, J.; Chen, Q. Antitumor activities of rauwolfia vomitoria extract and potentiation of gemcitabine effects against pancreatic cancer. Integr. Cancer Ther. 2014, 13, 217-225. [CrossRef] [PubMed]

130. Kapadia, G.J.; Rao, G.S.; Ramachandran, C.; Lida, A.; Suzuki, N.; Tokuda, H. Synergistic cytotoxicity of red beetroot (Beta vulgaris L.) extract with doxorubicin in human pancreatic, breast and prostate cancer cell lines. J. Complement. Integr. Med. 2013, 10, 113-122. [CrossRef]

131. Clarke, M.F.; Dick, J.E.; Dirks, P.B.; Eaves, C.J.; Jamieson, C.H.M.; Jones, D.L.; Visvader, J.; Weissman, I.L.; Wahl, G.M. Cancer stem cells-perspectives on current status and future directions: AACR Workshop on cancer stem cells. Cancer Res. 2006, 66, 9339-9344. [CrossRef] [PubMed]

132. Scarpa, E.S.; Ninfali, P. Phytochemicals as Innovative Therapeutic Tools against Cancer Stem Cells. Int. J. Mol. Sci. 2015, 16, 15727-15742. [CrossRef] [PubMed]

133. Sotiropoulou, P.A.; Christodoulou, M.S.; Silvani, A.; Herold-Mende, C.; Passarella, D. Chemical approaches to targeting drug resistance in cancer stem cells. Drug Discov. Today 2014, 19, 1547-1562. [CrossRef] [PubMed]

134. Fong, D.; Chan, M.M. Dietary phytochemicals target cancer stem cells for cancer chemoprevention. In Mitochondria as Targets for Phytochemicals in Cancer Prevention and Therapy, 1st ed.; Editor Chandra, D., Ed.; Springer: New York, NY, USA, 2013 ; pp. 85-125.

135. Naujokat, C.; McKee, D.L. The “Big Five" Phytochemicals Targeting Cancer Stem Cells: Curcumin, EGCG, Sulforaphane, Resveratrol and Genistein. Curr. Med. Chem. 2021, 28, 4321-4342. [CrossRef] [PubMed]

136. Taylor, W.F.; Jabbarzadeh, E. The use of natural products to target cancer stem cells. Am. J. Cancer Res. 2017, 7, 1588-1605.

137. Chan, M.M.; Chen, R.; Fong, D. Targeting cancer stem cells with dietary phytochemical—Repositioned drug combinations. Cancer Lett. 2018, 433, 53-64. [CrossRef]

138. Available online: https:/ / www.twinkl.it/resource/t-ar-64-human-liver-quick-look (accessed on 20 September 2021).

139. Buhrmann, C.; Kraehe, P.; Lueders, C.; Shayan, P.; Goel, A.; Shakibaei, M. Curcumin suppresses crosstalk between colon cancer stem cells and stromal fibroblasts in the tumor microenvironment: Potential role of EMT. PLoS ONE 2014, 9, e107514.

140. Chen, Y.; Wang, X.Q.; Zhang, Q.; Zhu, J.Y.; Li, Y.; Xie, C.F.; Li, X.T.; Wu, J.S.; Geng, S.S.; Zhong, C.Y.; et al. (-)-Epigallocatechin-3gallate inhibits colorectal cancer stem cells by suppressing Wnt/beta-catenin pathway. Nutrients 2017, 9, 572. [CrossRef]

141. Montales, M.T.; Simmen, R.C.; Ferreira, E.S.; Neves, V.A.; Simmen, F.A. Metformin and soybean-derived bioactive molecules attenuate the expansion of stem cell-like epithelial subpopulation and confer apoptotic sensitivity in human colon cancer cells. Genes Nutr. 2015, 10, 49-62. [CrossRef] [PubMed]

142. Huang, W.; Wan, C.; Luo, Q.; Huang, Z.; Luo, Q.; Huang, Z.; Luo, Q. Genistein-inhibited cancer stem cell-like properties and reduced chemoresistance of gastric cancer. Int. J. Mol. Sci. 2014, 15, 3432-3443. [CrossRef] [PubMed]

143. Tsai, C.F.; Hsieh, T.H.; Lee, J.N.; Hsu, C.Y.; Wang, Y.C.; Kuo, K.K.; Wu, H.L.; Chiu, C.C.; Tsai, E.M.; Kuo, P.L. Curcumin suppresses phthalate-induced metastasis and the proportion of cancer stem cell (CSC)-like cells via the inhibition of AhR/ERK/SK1 signaling in hepatocellular carcinoma. J. Agric. Food Chem. 2015, 63, 10388-10398. [CrossRef]

144. Shankar, S.; Nall, D.; Tang, S.N.; Meeker, D.; Passarini, J.; Sharma, J.; Srivastava, R.K. Resveratrol inhibits pancreatic cancer stem cell characteristics in human and KrasG12D transgenic mice by inhibiting pluripotency maintaining factors and epithelialmesenchymal transition. PLoS ONE 2011, 6, e16530. [CrossRef]

145. Ning, X.; Du, Y.; Ben, Q.; Huang, L.; He, X.; Gong, Y.; Gao, J.; Wu, H.; Man, X.; Jin, J.; et al. Bulk pancreatic cancer cells can convert into cancer stem cells (CSCs) in vitro and 2 compounds can target these CSCs. Cell Cycle 2016, 15, 403-412. [CrossRef] [PubMed]

146. Giovannucci, E. Epidemiology of vitamin D and colorectal cancer: Casual or causal link? J. Steroid. Biochem. Mol. Biol. 2010, 121, 349-354. [CrossRef] [PubMed]

147. Woolcott, C.G.; Wilkens, L.R.; Nomura, A.M.Y.; Horst, R.L.; Goodman, M.T.; Murphy, S.P.; Henderson, B.E.; Kolonel, L.N.; Le Marchand, L. Plasma 25-hydroxyvitamin D levels and the risk of colorectal cancer: The multiethnic cohort study. Cancer Epidemiol. Biomark. Prev 2010, 19, 130-134. [CrossRef] [PubMed]

148. Freedman, D.M.; Looker, A.C.; Chang, S.C.; Graubard, B.I. Prospective study of serum vitamin D and cancer mortality in the United States. J. Natl. Cancer Inst. 2007, 99, 1594-1602. [CrossRef] [PubMed] 
149. Jenab, M.; Bueno-de-Mesquita, H.B.; Ferrari, P.; van Duijnhoven, F.J.B.; Norat, T.; Pischon, T.; Jansen, E.H.J.M.; Slimani, N.; Byrnes, G.; Rinaldi, S.; et al. Association between pre-diagnostic circulating vitamin D concentration and risk of colorectal cancer in European populations: A nested case-control study. Biochem. Med. J. 2010, 340, b5500.

150. Gandini, S.; Boniol, M.; Haukka, J.; Byrnes, G.; Cox, B.; Sneyd, M.J.; Mullie, P.; Autier, P. Meta-analysis of observational studies of serum 25-hydroxyvitamin d levels and colorectal, breast and prostate cancer and colorectal adenoma. Int. J. Cancer 2011, 128, 1414-1424. [CrossRef] [PubMed]

151. Maalmi, H.; Ordonez-Mena, J.M.; Schottker, B.; Brenner, H. Serum 25-hydroxyvitamin D levels and survival in colorectal and breast cancer patients: Systematic review and meta-analysis of prospective cohort studies. Eur. J. Cancer 2014, 50, 1510-1521. [CrossRef] [PubMed]

152. Ma, Y.; Zhang, P.; Wang, F.; Yang, J.; Liu, Z.; Qin, H. Association between vitamin D and risk of colorectal cancer: A systematic review of prospective studies. J. Clin. Oncol. 2011, 29, 3775-3782. [CrossRef]

153. Farzaei, M.H.; Bahramsoltani, R.; Rahimi, R. Phytochemicals as Adjunctive with Conventional Anticancer Therapies. Curr. Pharm. Des. 2016, 22, 1-18.

154. Fujiki, H.; Sueoka, E.; Watanabe, T.; Suganuma, M. Primary cancer prevention by green tea, and tertiary cancer prevention by the combination of green tea catechins and anticancer compounds. J. Cancer Prev. 2015, 20, 1-4. [CrossRef]

155. Howells, L.L.; Berry, D.P.; Elliott, P.J.; Jacobson, E.W.; Hoffmann, E.; Hegarty, B.; Brown, K.; Steward, W.P.; Gescher, A.J. Phase I randomized, double-blind pilot study of micronized resveratrol (SRT501) in patients with hepatic metastases-safety, pharmacokinetics, and pharmacodynamics. Cancer Prev. Res. 2011, 4, 1419-1425. [CrossRef] [PubMed]

156. James, M.I.; Iwuji, C.; Irving, G.; Karmokar, A.; Higgins, J.A.; Griffin-Teal, N.; Thomas, A.; Greaves, P.; Cai, H.; Patel, S.R.; et al. Curcumin inhibits cancer stem cell phenotypes in ex vivo models of colorectal liver metastases, and is clinically safe and tolerable in combination with FOLFOX chemotherapy. Cancer Lett. 2015, 364, 135-141. [CrossRef]

157. Dhillon, N.; Aggarwal, B.B.; Newman, R.A.; Wolff, R.A.; Kunnumakkara, A.B.; Abbruzzese, J.L.; Ng, C.S.; Badmaev, V.; Kurzrock, R. Phase II trial of curcumin in patients with advanced pancreatic cancer. Clin. Cancer Res. 2008, 14, 4491-4499. [CrossRef]

158. Kanai, M. Therapeutic applications of curcumin for patients with pancreatic cancer. World J. Gastroenterol. 2014, $20,9384-9391$. [PubMed]

159. Kanai, M.; Yoshimura, K.; Asada, M.; Imaizumi, A.; Suzuki, C.; Matsumoto, S.; Nishimura, T.; Mori, Y.; Masui, T.; Kawaguchi, Y.; et al. A phase I/II study of gemcitabine-based chemotherapy plus curcumin for patients with gemcitabine resistant pancreatic cancer. Cancer Chemother. Pharmacol. 2011, 68, 157-164. [CrossRef] [PubMed]

160. Epelbaum, R.; Schaffer, M.; Vizel, B.; Badmaev, V.; Bar-Sela, G. Curcumin and gemcitabine in patients with advanced pancreatic cancer. Nutr. Cancer 2010, 62, 1137-1141. [CrossRef] [PubMed]

161. Li, Y.; Wicha, M.S.; Schwartz, S.J.; Sun, D. Implications of cancer stem cell theory for cancer chemoprevention by natural dietary compounds. J. Nutr. Biochem. 2011, 22, 799-806. [CrossRef]

162. Surh, Y.J. Cancer chemoprevention with dietary phytochemicals. Nat. Rev. Cancer 2003, 3, 768-780. [CrossRef] [PubMed]

163. Zhang, M.; Chen, X.; Radacsi, N. New tricks of old drugs: Repurposing non-chemo drugs and dietary phytochemicals as adjuvants in anti-tumor therapies. J. Control. Release 2021, 329, 96-120. [CrossRef] [PubMed]

164. Fan, J.X.; Zheng, D.W.; Rong, L.; Zhu, J.Y.; Hong, S.; Li, C.; Xu, Z.S.; Cheng, S.X.; Zhang, X.Z. Targeting epithelial-mesenchymal transition: Metal organic network nano-complexes for preventing tumor metastasis. Biomaterials 2017, 139, 116-126. [CrossRef] [PubMed]

165. Tyagi, N.; De, R.; Begun, J.; Popat, A. Cancer therapeutics with epigallocatechin-3-gallate encapsulated in biopolymeric nanoparticles. Int. J. Pharm. 2017, 518, 220-227. [CrossRef] [PubMed]

166. Kumar, B.N.P.; Puvvada, N.; Rajput, S.; Sarkar, S.; Mahto, M.K.; Yallapu, M.M.; Pathak, A.; Emdad, L.; Das, S.K.; Reis, R.L.; et al. Targeting of EGFR, VEGFR2, and Akt by engineered dual drug encapsulated mesoporous silica-gold nanoclusters sensitizes tamoxifen-resistant breast cancer. Mol. Pharm. 2018, 15, 2698-2713. [CrossRef] [PubMed] 